Revue

del'histoire des religions

\section{Revue de l'histoire des religions}

$2 \mid 2015$

Les images miraculeuses de la Vierge au premier âge moderne entre dévotion locale et culte universel

\title{
The architecture of miracle-working statues in the
}

Southern Netherlands

L'architecture des statues miraculeuses dans les Pays-Bas méridionaux

Maarten Delbeke, Lobke Geurs, Lise Constant and Annelies Staessen

\section{(2) OpenEdition}

Journals

Electronic version

URL: http://journals.openedition.org/rhr/8396

DOI: $10.4000 /$ rhr.8396

ISSN: 2105-2573

\section{Publisher}

Armand Colin

\section{Printed version}

Date of publication: 1 June 2015

Number of pages: $211-256$

ISBN: 978-2-200-92965-7

ISSN: 0035-1423

Electronic reference

Maarten Delbeke, Lobke Geurs, Lise Constant and Annelies Staessen, «The architecture of miracleworking statues in the Southern Netherlands », Revue de l'histoire des religions [Online], 2 | 2015, Online since 01 June 2018, connection on 25 April 2019. URL : http://journals.openedition.org/rhr/8396 DOI : 10.4000/rhr.8396 
MAARTEN DELBEKE

Universiteit Gent / Universiteit Leiden

\section{LISE CONSTANT}

Universiteit Gent / Université catholique

de Louvain
LOBKE GEURS

Universiteit Gent
ANNELIES STAESSEN

Universiteit Gent

\section{The architecture of miracle-working statues in the Southern Netherlands}

In the $17^{\text {th }}$ century, the Southern Netherlands saw the erection or restoration of numerous sanctuaries dedicated to the Virgin Mary. In many cases, they housed a miracle-working statue. This essay analyzes the architecture of these sanctuaries through the histories that were written about their statues. It examines how the history of the statues, as recorded in contemporary textual and visual sources, represents and interprets their material surroundings, including the architecture, in order to understand how the statues were thought to relate to these surroundings. Three types of historical narratives are distinguished, each explaining the presence and actions of a statue on its site. These three types will, in turn, shed light on the characteristics and development of the material surroundings of the miracle-working statues.

\section{L'architecture des statues miraculeuses dans les Pays-Bas méridionaux}

Au XVII siècle, les Pays-Bas méridionaux voient la construction ou la restauration de nombreux sanctuaires dédiés à la Vierge qui, pour la plupart, abritent une statue miraculeuse. Cet essai analyse l'architecture de ces sanctuaires à partir des récits écrits sur ces statues. Il examine comment l'histoire des statues, enregistrée dans les sources textuelles et iconographiques contemporaines, représente et interprète leur environnement matériel, incluant l'architecture, afin de comprendre le lien que ces statues étaient supposées entretenir avec ce cadre. Trois types de récits sont distingués, chacun expliquant la présence et les actions d'une statue sur son site. À tour de rôle, ces trois types mettront en lumière les caractéristiques et le développement de l'environnement matériel des images miraculeuses. 


\section{INTRODUCTION}

Like other European regions implicated in confessional strife and bordering Protestant territories, the Southern Netherlands laid claim to a dense network of miraculous manifestations of the Virgin Mary, considered a protection and a guarantee for the eventual redemption of the land. The distribution of miracle-working statues, the tangible residue of Mary's special presence, established a regional Marian topography. ${ }^{1}$ As publications like Wilhelm Gumppenberg's Atlas Marianus (1657) testify, this local topography formed part of an ultimately global network of images, statues and shrines, believed to direct divine grace to particular places and to foster devotion.

Regardless of their exact provenance, at a certain point in their history the numerous statues required shelter: either to protect them from the elements or from heretics as well as all-too-eager worshippers; to signal their presence in the landscape; to collect gifts and votive offerings; and to organize and accommodate cult and pilgrimage. Historians of architecture have long been interested in the centrally planned churches that developed from the Quattrocento onwards as the privileged typology for housing miraculous representations of Mary. ${ }^{2}$ Studies on Central European

Research for this article was made possible by a project grant from the F.W.O. - Research Foundation Flanders. It is based on an extensive survey of shrines of miracle-working statues of the Virgin executed by Lise Constant, Lobke Geurs and Annelies Staessen under the direction of Maarten Delbeke.

1. Annick Delfosse, La "Protectrice du Païs-Bas". Stratégies politiques et figures de la Vierge dans les Pays-Bas espagnols, Turnhout, Brepols, 2009.

2. Wolfgang Lotz, "Notizen zum kirchlichen Zentralbau der Renaissance", Studien zur Toskanischen Kunst (Festschrift L.H. Heydenreich), ed. Wolfgang Lotz and Lise Lotte Möller, München, Prestel, 1964, p. 157-165; Georg Mörsch, Der Zentralbaugedanke im Belgischen Kirchenbau des 17. Jahrhundert, Diss., Rheinische Friedrich-Wilhelms Universität, Bonn, 1965; Staale Sinding-Larsen, "Some functional and iconographical aspects of the centralized church in the Italian Renaissance", Acta ad archaeologiam et artium historiam pertinentia, 2, 1965, p. 203-252; Claudia Conforti, "Cupole, chiese a pianta centrale e culto mariano nel Rinascimento italiano", Lo specchio del cielo: forme significati tecniche e funzioni della cupola dal Pantheon al Novecento, ed. Claudia Conforti, Milan, Electa, 1997, p. 67-85; Paul Davies, "La santità del luogo e la chiesa a pianta centrale nel Quattro e primo Cinquecento", La chiesa a pianta centrale. Tempio civico del Rinascimento, ed. Bruno Adorni, Milan, Electa, 2002, p. 27-35 as well as Davies' important studies of pilgrimage churches; Erik Thun $\varnothing$, "The miraculous image and 
religious architecture have explored how the veneration of miracleworking statues inspired experiments with central ground plans, ${ }^{3}$ as did Joris Snaet in his foundational study of a series of Marian churches in the $17^{\text {th }}$ century Low Countries. ${ }^{4}$

In this essay, we propose to analyze the architecture of Marian chapels and churches by taking the miracle-working statues of the Virgin and their history as our starting point. We examine how the history of statues recorded in contemporary textual and visual documents represents and interprets their material surroundings, including the architecture, in order to understand how the statues were thought to relate to these surroundings. This analysis allows us to investigate how the design of these surroundings reflects contemporary ideas about the statues, their nature and their meaning.

In the wake of the Catholic re-conquest of the Southern Netherlands territories from the late $16^{\text {th }}$ century onwards, the rapid spread of the cult of miracle-working statues and the restoration or rebuilding of churches, as well as the installation of sacred images, were supported by an important body of historiography. ${ }^{5}$ Numerous histories reframed older legends and myths of origin in a historical discourse. ${ }^{6}$ They often carried illustrations and were aimed

the centralized church Santa Maria della Consolazione in Todi”, The Miraculous Image in the Late Middle Ages and the Renaissance, ed. Erik Thun $\varnothing$ and Gerhard Wolf, Rome, L'erma di Bretschneider (“Analecta Romana Instituti Danici”, Suppl. Xxxv), 2004, p. 29-56.

3. Pierre Charpentrat, Du maître d'ouvrage au maître d'œuvre, l'architecture religieuse en Allemagne du Sud, de la guerre de Trente Ans à l'Aufklärung, Paris, Klincksieck, 1974.

4. Joris Snaet, "For the Greater Glory of God. Religious Architecture in the Low Countries 1560-1700", Unity and Discontinuity. Architectural Relations between the Southern and the Northern Low Countries 1530-1700, ed. Krista De Jonge and Konrad Ottenheym, Turnhout, Brepols, 2007, p. 293-297. See also Krista De Jonge, "Aux frontières du monde catholique. Églises de plan centré dans les Pays-Bas méridionaux au XVII ${ }^{\mathrm{e}}$ siècle", L'architecture religieuse européenne au temps des Réformes: héritage de la Renaissance et nouvelles problématiques, ed. Monique Chatenet and Claude Mignot, Paris, Picard, 2009, p. 79-89.

5. See A. Delfosse, La "Protectrice du Païs-Bas", p. 25-54.

6. On this body of myths, see Conrad Rudolph, "Building-Miracles as Artistic Justification in the Early and Mid-Twelfth Century", Radical Art History: Internationale Anthologie, ed. Kersten Wolfgang, Zürich, Zürich Interpublishers, 1997, p. 398-410; Jules Pieters, "Een paar motieven uit Oostvlaamse bouwlegenden", Volkskunde, 2, 1956, p. 1-13. See also Ingmar Reesing and Michael Hoyle, "Notre-Dame de Foy: The Reuse and Dissemination of a Late 
at a general audience. Most were written by priests or dignitaries who drew upon local archives and traditions as well as on the more learned accounts provided by historians such as Petrus Canisius and Ferreolus Locrius (Ferry de Locre), who published universal histories of the cult of the Virgin, De Maria Virgine (1577) and Maria Augusta virgo Deipara (1608). ${ }^{7}$ From these treatises, learned references and tropes trickled into the often vernacular miracle books, where they shaped the discourse on all aspects of miraculous images, including their appropriate veneration and accommodation. ${ }^{8}$ The literary accounts helped to establish an iconography of the history of the statues, while existing iconography inspired the historiography. ${ }^{9}$

The accounts are replete with conventions that are not necessarily peculiar to miracle-working statues of Mary, the $17^{\text {th }}$ century or the Southern Netherlands. Without exception, they explain how the cult of the statue began, often by examining the origin of the statue itself: the place where it was found, the paths by which it emerged, or the miraculous event that signaled its existence. In many cases, the cult is framed in the larger history of the veneration of the Virgin, and connected with well-known miracle-working images venerated in other geographical areas. The histories trace a narrative from these origins to contemporary times and local places. By listing interventions in the surroundings of the statue, identifying donors, and relating how the statue performed in its

Medieval Figurine of the Virgin in the Low Countries", Simiolus: Netherlands Quarterly for the History of Art, 33, 3, 2007/2008, p. 145-165.

7. A. Delfosse, La "Protectrice du Païs-Bas", p. 39-40.

8. On these histories, see, besides the literature quoted in the previous notes: Alfons K. L. Thijs, Antwerpen, Internationaal uitgeverscentrum van devotieprenten, 17de-18de eeuw, Louvain, Peeters, 1993; Idem, "Over bedevaarten in Vlaanderen: van stichtelijke propaganda naar wetenschappelijke interesse", Volkskunde. Tijdschrift voor de studie van het volksleven, 97, 3, 1996, p. 272-349; Ralph Dekoninck, "Défense et illustration du culte de Notre-Dame de Foy. L'Abrégé de l'histoire de Notre-Dame de Foy de Louis Lipsin (1734)", Annales de la société archéologique de Namur, 83, 2009, p. 205-213; Annick Delfosse, "La Vierge comme protectrice des Pays-Bas méridionaux dans les livrets de pèlerinage marial au XVII ${ }^{\mathrm{e}}$ siècle", Revue belge de philologie et d'histoire, 80, 4, 2002, p. 1225-1241.

9. For example, in his account of the history of the "Goede Bijstand" church in Brussels, Van Tichelen points out that the statuette, wrapped in cloth and found by the caretaker, originally came from another place of worship, where it was known as "Our Lady in the Vineyard". The image still carries grapes in one hand as a reminder of this history. See Joseph Van Tichelen, À l'Ombre d'un Vieux Sanctuaire, Brasschaat, De Bièvre, 1925, p. 28-29. 
environment, they aimed to account for the state of the statue's material surroundings at the time of their publication.

In this essay, we intend to demonstrate how these accounts provide a valuable starting point for the analysis and interpretation of the material context of miracle-working statues. First, we present a typology of historical accounts of miracle-working statues. While the accounts are highly conventional, closer analysis reveals distinct narrative strategies that serve to explain how a statue emerges, finds a place, and becomes an object of devotion. Each account attempts to elucidate how Mary's presence, embodied in a statue, became anchored in a particular place, at a particular moment in history. We will distinguish three different types of narratives, each explaining the presence and actions of a statue on its site in the present. Then we will ask whether and how these three types of narratives contribute to our understanding of the material surroundings of the miracleworking statues. To do so, we will first distinguish a set of themes that occur across the three types of narrative and offer indications about the characteristics of the statue's surroundings, and then focus on characteristics that are specific to each type of narrative. In the final section, we will briefly discuss how our method sheds light on the role of these shrines in the religiosity of the $17^{\text {th }}$ century Southern Netherlands.

In order to manage the significant amount of miracle-working statues and their histories across the Low Countries, the cases have been limited largely to the Duchy of Brabant in the $17^{\text {th }}$ century. Augustinus Wichmans' Brabantia Mariana (1632), a history of sixty-six Marian shrines preceded by a history of the cult of the Virgin, has provided the geographical starting point for our research. ${ }^{10}$ We have expanded the set provided by Wichmans by incorporating

10. Wichmans' inventory contains a dozen of Marian shrines in Northern Brabant, in the area of 's-Hertogenbosch (Bois-le-Duc), which fell under protestant control after 1629. While our research deals mainly with shrines of Southern Brabant, an overview of these northern places of worship, their stories, related material culture and sources, can be found in the online database "Shrines and Pilgrimage in the Netherlands" of the Meertens Instituut (KNAW): www.meertens.knaw.nl/ bedevaart/. On Catholic pilgrimages in the Netherlands, see Marc Wingens, Over de grens: de bedevaart van katholieke Nederlanders in de zeventiende en achttiende eeuw, Nijmegen, SUN ("Memoria: cultuur- en mentaliteithistorische studies over de Nederlanden", 2), 1994. 
information from later Marian historiography. ${ }^{11}$ Where appropriate, we have examined cults outside Brabant, to gauge, for instance, the role of the Norbertines or Premonstratensians in the promotion of the cult of the Virgin, as a case study of how religious orders might establish or reinforce networks of miracle-working statues and their shrines. The historiographical survey determined the selection of sanctuaries that would be examined, and served as a first guide for identifying material, visual and textual sources about the material surroundings of the statue, its history, and its representation. ${ }^{12}$ This selection is not aimed at proving the peculiarity of the cult of Mary and her miracle-working statues in our area of study: quite the contrary. As pointed out, and discussed in an important body of scholarship, the cult of Mary and the devotion to miracle-working statues developed across the global Catholic sphere of influence, and was supported by powerful patrons such as the Spanish and Austrian Habsburgs as well as the French monarchy or the Roman papacy. ${ }^{13}$ By examining a fragment of this phenomenon, we wish to propose an approach to the study of the architecture for miracleworking statues that can be tested in other geographical contexts as well.

11. Abbé H. Maho, La Belgique à Marie. Belgium Marianum. Répertoire historique et descriptif des Églises, Sanctuaires, Chapelles et Grottes dans nos Provinces, Brussels, A. Bieleveld, 1927; Auguste-Joseph de Reume, Les vierges miraculeuses de la Belgique. Histoire des sanctuaires où elles sont vénérées. Légendes, pèlerinage, confrérie, bibliographie, Tournai, Casterman, 1878; P. Fr. Stephanus Schoutens, Maria's Brabant of beschrijving van de Wonderbeelden en merkweerdige Bedevaartplaatsen van Onze-Lieve-Vrouw in Brabant, Sint-Truiden, Schouberechts-Vanwest, 1878.

12. In a list of 120 Marian shrines, we have selected 49 stories of sanctuaries developed around a miraculous image. Of these, 29 are listed in Wichmans' Brabantia Mariana or other $17^{\text {th }}$ century publications. The editions of miracle books quoted in the following notes were retrieved from Karen L. Bowen, Marian Pilgrimage sites in Brabant. A Bibliography of Books printed between 1600-1850, Louvain, Peeters ("Miscellanea Neerlandica", XXXVII), 2008.

13. Besides A. Delfosse, La "Protectrice du Païs-Bas", see Jeffrey Schrader, La Virgen de Atocha. Los Austrias y las imágenes milagrosas, Madrid, Ayuntamiento de Madrid, 2006; Javier Portus Pérez, El culto a la Virgen en Madrid durante la Edad Moderna, Madrid, Comunidad de Madrid ("Biblioteca básica madrileña", 17), 2000; Bruno Maes, Le roi, la vierge et la nation: pèlerinages et identité nationale entre guerre de Cent Ans et Révolution, Paris, Publisud ( «La France au fil des siècles»), 2003; Franz Matsche, "Gegenreformatorische Architekturpolitik: Casa-Santa-Kopien und Harbsburger Loreto-Kult nach 1620", Jarhbuch für Volkskunde, 1, 1978, p. 81-118 


\section{Three TYPeS OF ACCOUNTS}

In order to make the historical accounts of miracle-working statues available for further analysis, they are classified according to how they relate miraculous events in the statue's history to both the place of its original invention and the circumstances of its eventual worship. This distinction establishes three types of accounts that vary from histories that identify a miraculous event as the origin of a particular building, to narratives where the statue itself is the primary agent of miracles. In what follows, we provide a brief characterization and illustration of the three types, and conclude with a range of hybrids.

In the first type of accounts, a miraculous foundation is at the center: a divine intervention establishes a shrine. This type encompasses several stories according to which a thread of divine origin designates the place of worship and traces the building plan and proportions. The thread forms the material manifestation of Mary's will to build a shrine in a particular place, often after it had been initiated by human builders according to a different design or at another location. The best-known example of this type is Our Lady of Laken, north of Brussels, where Mary would demolish the work of the builders until they follow her instructions: the idiosyncratic, southern-oriented plan of the church, laid out with a thread (fig. 1). ${ }^{14}$ Human actors originally decided to found a place of worship, but the intervention of the Virgin during the construction initiates the miraculous story. Similarly, in the case of Our Lady of Alsemberg, the $17^{\text {th }}$ century account by Lucas Van Lathem relates how, in the

14. Quentin Hennin, Origine de l'église miraculeuse de Lacq. Trophée de la religion catholique, après la défaite des infidelles dans les Pais-Bas. Par l'empereur Arnulphe Roy de Bavière l'an 895. Erigée à la Reine du ciel par deux vierges, sœurs de Hugue, duc de Germanie et de Loraine, enseveli au Lacq sous la ruine des Normans, Brussels, Nicolas Stryckwant, n. d.. Approved in 1694, Hennin's account follows several publications recalling the story of the church of Laken: Laurentius Van Beneden, Historie vande kercke van Christus gewydt, beelt, draet, ende machtighe wercken vande soete Moeder Godts Maria te Laken, by Brussel. Met een blinckende gouden keten des lofs Maria, Brussels, Huybrecht Anthoon, 1624, also translated in Spanish; Joannes Anthonius À Gurnez, Laca Bruxellens suburbanum cultu ac prodigiis Deiparae, a Normannorum temporibus, id est, ante omnia Parthenijs aedibus \& iconibus miraculosis in Belgio loca clara, celebris, novo studio illustrate, Brussels, Godfridum Schovartium, 1647. 
course of the $13^{\text {th }}$ century, a divine thread appeared at every stage of the building process. ${ }^{15}$

Miraculous foundations are not confined to churches designed with a thread. Histories of the origins of the cult of Basse-Wavre ${ }^{16}$ (fig. 2) relate how, in 1050, the manifestation of "celestial hummings, and angelic music, married to suprahuman instruments" ${ }^{17}$ in a marsh inspired the faithful to erect a chapel on a nearby hill, since the site of the apparitions was deemed unfit for construction. In a chain of events similar to Laken, each night the Virgin and angels undid the work of the day and rebuilt it in the marshy valley. In these cases, devotion eventually accrued around one or more statues of the Virgin. They were often credited with miracles but had no direct bearing on the origin story.

A second type of accounts encompasses statues with a historical pedigree. The statue derives its importance from its lineage and the royal or other patronage it attracted. An important set of such stories concerns statues gifted by St Elizabeth of Hungary and her descendants over the course of the $13^{\text {th }}$ century. As the widow of Louis, Landgrave of Thuringia, Elizabeth dedicated her life and goods to the assistance of the poor. ${ }^{18}$ The miracle-working statues associated with her draw their importance from the venerability

15. Lucas Van Lathem, Historie der mirakuleuse Kercke van onse L. Vrouwe tot Alsenberghe; Ghesticht door de H. Elizabeth. Vermeerdert door Joannes den derde Hertogh van Brabandt. Volbouwt door d'in-ghesetene van Alsenberghe. By-een vergadert door H. L. V. Lathem, Bach. Form. in de H. Godtheydt, ende P. tot Alsenberghe, Brussels, Guilliam Scheybels, 1643. Several editions of this text, published in the late $17^{\text {th }}$ or $18^{\text {th }}$ century, are preserved in both French and Dutch. We used the following edition: Lucas Van Lathem, Histoire de la devote et miraculeuse eglise de N. Dame d'Alsemberghe: Batie par S. Elizabeth, Fille du Roi de Hongrie, augmentée par Jean III. Duc de Brabant \& depuis achevée, de bâtir par les habitans dudit Alsemberg, Brussels, Jean van Vlaenderen, n. d. [approved in 1643], here p. 11, 15, 19, 20-21.

16. L'arche d'Alliance ou l'Histoire de Notre-Dame de la Basse Wavre; dict Nostre Dame de Payx et Concord, n. p. n. d. [approved in 1641], p. 8-17. The foundation story of Basse-Wavre probably dates from the late $15^{\text {th }}$ century. For the books relating the story of Our Lady of Basse-Wavre, see Basse-Wavre (1628-1978). 350 anniversaire de la donation de la châsse par l'archevêque de Malines Jacques Boonen en 1628, Wavre, Cercle Historique et Archéologique de Wavre et de la Région, 1978, p. 17-22.

17. L'arche d'Alliance, p. 9.

18. Justus Lipsius, La Nostre Dame de Hau, ses bienfaicts, et miracles fidelement recueillis \& arrengez en bel ordre, trans. M. Louys du Gardin de Mortaigne, Brussels, Hubert Anthoine Velpius, 1643, p. 5-11. 
of the holy donor. The statue of Our Lady of Halle belongs to this category, as it was gifted by Machtilde, the sister-in-law of Elizabeth's daughter Sophie through the latter's marriage with Henri II, Duke of Brabant. ${ }^{19}$ Marian historiography attributes the importance of Halle as a Marian pilgrimage site to this gift. Our Lady of Consolation (Onze-Lieve-Vrouw van Troost) in Vilvoorde (fig. 3), too, is traced back to St Elizabeth and Sophie, who offered the statue to a community of poor women who took care of the hospital she had founded in Peuthy. ${ }^{20}$ Marian historiography also associated St Elizabeth with Our Lady of Alsemberg. ${ }^{21}$

Besides the statues linked to St Elizabeth and her descendants, several other miracle-working statues were valued primarily as gifts from religious and secular individuals. For instance, St Peter's Church in Leuven successively kept two miraculous statues offered by different actors. ${ }^{22}$ Illustrious patrons often played an important

19. Justus Lipsius, Diva Virgo Hallensis. Beneficia eius miracula fide atque ordine descripta, Antwerp, Plantin, Jean Moretus, 1604, has been reprinted, edited and translated several times. In 1651, Claude Maillard (1586-1655) relied on the work by Lipsius to rewrite the history of the sanctuary in French: Claude Maillard, Histoire de Nostre Dame de Hale. Divisée en trois parties. La première de la Ville, de l'Image \& de l'Eglise. La seconde des merveilles et miracles. La troisième des honneurs deferez à noste Dame de Hale, Brussels, Hubert Antoine Velpius, 1651.

20. J. Compaignom, Histoire de l'image admirable de Nostre Dame de Consolation, Reverée dans l'Eglise du Monastère des Religieuses Carmélites de Vilvorde, Brussels, Guillaume Scheybels, 1648; K. L. Bowen, Marian Pilgrimage sites, p. 307-311, mentions several editions of a story of 'Onze-Lieve-Vrouw van Vilvoorde' in Dutch, for example: Kort begryp der historie Van het oud vermaerd Mirakuleus Beeld van O.L.Vrouwe van Troost, Rustende tot Vilvoorden in de Kerke der Carmeliterssen (sic), Joannes van Vlaenderen, n. p. n. d. These editions are undated but were published by printers active between the early $18^{\text {th }}$ and late $19^{\text {th }}$ century.

21. L. Van Laethem, Histoire de la devote, p. 28-32.

22. The story of the Our Lady of Leuven cult was written in Latin by Bernard Heymbach in 1655: Bernard Heymbach, Diva Lovaniensis seu mira beneficia a dei parente Lovanii ad aram sibi sacram in aede D. Petri Mortalibus Impetrata. Libri tres, Louvain, Cypriani Coenestenij, 1655. In 1757, M. G. Van der Buecken published Wonderen bystandt van de alder-heylighste maeght ende moeder Godts Maria, bethoont aen haere getrouwe dienaers in de vermaerde collegiaele ende parochiaele hooftkercke van den heyligen Petrus binnen Loven, hooft-stadt van Brabant, Louvain, Théodore C. J. De Zangre, 1757. An unpublished manuscript of Justus Lipsius has been discovered and published by J. de Landtsheer: Justus Lipsius, Diva Virgo Lovaniensis, trans. J. de Landtsheer, Wildert, De Carbolineum Press, 1999. On this work, see Jeanine De Landtsheer, "Iusti Lipsi Diva Lovaniensis: an unknown treatise on Louvain's Sedes Sapientiae", Revue d'Histoire Ecclésiastique, 92, 1997, p. 135-142. 
role in the distribution of copies of statues. For example, the Archdukes used copies of the Scherpenheuvel Virgin (Onze-LieveVrouw van Scherpenheuvel / Notre-Dame de Montaigu) as prized diplomatic gifts, and they can be found in Villers-La-Ville, Izegem, Antwerp and in the church of the Jesuits at Tournon in France as well as across Europe. ${ }^{23}$

In the third type of account, by far the most common, ${ }^{24}$ the statue itself is involved in some miraculous event, which may occur at different stages of the history of the shrine.

First, a divine intervention determines the place of worship of an available image. This can occur according to two scenarios. In a first type of scenario, an apparition of the Virgin Mary indicates where she wishes to be honored. Our Lady of Grace (Onze-LieveVrouw van Gratie) in Scheutveld, near Anderlecht, is a good example, as well as Our Lady of the Zavel (Onze-Lieve-Vrouw van de Zavel/Notre-Dame du Sablon). ${ }^{25}$ In this particular case, the Virgin appeared to a woman, Beatrix Soetkens, whom she ordered to restore a neglected statue in a church of Antwerp, and then to take it by boat to Brussels, where the Duke Jan II installed it in the Zavel church. ${ }^{26}$ In a second type, the statue itself assumes an active role in identifying the place of worship, for instance by immobilizing a ship or a coach. Examples include Our Lady of Zemst, Hanswijk, Aarschot, Merchtem and Berendrecht. ${ }^{27}$ It also

23. Luc Duerloo and Marc Wingens, Scherpenheuvel. Het Jeruzalem van de Lage Landen, Louvain, Davidsfonds, 2002, p. 58-59.

24. Of the 49 selected cases, 31 belong to the third type, 6 to the first and 9 to the second type. Three accounts combine two types.

25. On Scheutveld, see S. Schoutens, Maria's Brabant, p. 24-25.

26. Jean Magnus, Histoire de l'Image de N. Dame du Sablon. Arrivée miraculeusement de la ville d'Anvers en la Roiale Cité de Brusselles l'An 1348, Brussels, Jacques vande Velde, n. d., p. 5-19; A. Wichmans, Brabantia Mariana, p. 290-293; S. Schoutens, Maria's Brabant, p. 38-39.

27. On Zemst, see: Historie van Onze Lieve Vrouw in het Hammeken onder het dorp Sempse. Opnieuw opgesteld en vermeerdert met merkweerdige byzonderheden, Mechelen, P. J. Hanicq, 1828; On Hanswijk, see: Petrus Croon, Historie van Onse Lieve Vrauwe van Hanswyck door haer audt ende Mirakuleus Beeldt eertydts buyten nu binnen Mechelen Besonderlijck Vermaert, Mechelen, Gysbrecht Lints, 1670 and Petrus Siré, Hanswyck ende het wonderdadigh beeldt van de alder-heylighste Maget ende Moeder Godts Maria Eertys buyten, nu binnen Mechelen, Dendermonde, Jacobus Ducaju, 1738; On Aarschot, see: Kort Begryp van de stadt Aerschot, synde een Hertoghdom in Brabant, Haere opkomste, met eene korte beschryvinge van het Beeldt der Moeder Godts, aldaer in de Collegiaele Kercke Miraculeuselyck rustende (...), Brussels, J. B. Jorez, 1766; On 
occurs that the statue miraculously returns to the place where it was initially found to indicate where it wishes to be worshipped, regardless of how insalubrious, unworthy or unsafe the place may be. In the miraculous history of Our Lady in the Field (Onze-LieveVrouw van den Akker) in Minderhout, the statue returns five times to the place of its discovery. ${ }^{28}$

Apart from these instances where a statue directs worshippers to a particular place, many miraculous founding stories associate statues with trees. Either the miraculous appearance of the statue in a tree instigates the cult, as in Duffel (fig. 4), or a statue attached to a tree at an unknown moment in history suddenly starts to perform miracles. In Kortenaken, for example, a statue, Our Lady of the Source (Onze-Lieve-Vrouw Ter Bron), hung in a small cabinet on a tree. It derived its name from the creek next to it. Devotees suffering from fever prayed here to the Virgin to be cured from their illness. In a later phase, a chapel was constructed to shelter the worshippers from the elements. ${ }^{29}$ In a third variety of accounts, a statue of the Virgin (miraculously found or bought) performs miracles once it is placed in a tree. Besides Scheutveld, Kortenbos, Braine-le-Château, Retie, Zoutleeuw, and Averbode, this is the case in Jezus-Eik, where a man, Petrus van den Kerkhove, bought a statue with the intention of hanging it in a tree. Only three years later his son fulfilled the vow, and placed the statue in a small cabinet attached to the "Jesus Oak". 30

Finally, some shrines housing a miracle-working statue were built to fulfill a pledge, often after a miraculous intervention of the Virgin in battle; in these instances, the pledge and the miracle it engenders precede and, to some extent, instigate the cult. Our Lady on a Mule (Onze-Lieve-Vrouw ter Muylen) in Liedekerke is a statue of Mary seated on a mule, commissioned in fulfillment of a pledge made

Merchtem, see: S. Schoutens, Maria's Brabant, p. 116-119; On Berendrecht, see: G. Geerts, "De kapel van de Hagelberg te Berendrecht, 1732-1982", Polderheem. Heemkundige Kring van de Antwerpse Polder, 17, 3, 1982, p. 9-86.

28. J. Heylaerts, Beknopte geschiedenis van Onze-Lieve-Vrouw van Minderhout, Hoogstraten, Van Hoof-Roelans, 1904; H. Maho, La Belgique à Marie, p. 368-369. We have not been able to trace earlier sources for this story.

29. S. Schoutens, Maria's Brabant, p. 71.

30. Bartholomeus Seghers, Den pelgrim van Sonien-Bosch naer de H. Maghet Maria van Jesukens-Eyk, inhoudende den oorsprong, voortgang en mirakeleuse teekenen aldaer geschied, Brussels, De Wageneer, n. d. 
by the bannerets of Liedekerke when they were entrapped during the $13^{\text {th }}$ century crusades. ${ }^{31}$ Similar stories are associated with the statues of Ittre, Wever, Ukkel, Calevoet and Averbode.

Defining the three types of accounts and identifying the different categories within each type helps to structure the large number of tales. Moreover, the distinctions also reveal the complexity of many cases. In several instances, different stories of how the statue emerged in the world are available. For example, Van Heurck gives two different accounts on how Our Lady of the Hagelberg in Berendrecht became the center of a new place of worship. In the first version the statue was found in a hedge and brought to the parish church. The next morning, the statue had returned to its original place in the hedge, indicating that Mary wanted to be worshipped in this humble place. As a consequence, it was decided to build a chapel there. In the second version, the statue was found by the mayor of Santvliet when he passed a hedge on horseback. His horse refused to go any further; when he dismounted, he saw the statue in the hedge and decided to have a chapel built on that very location. ${ }^{32}$

Conversely, several accounts incorporate characteristics of more than one type of narrative. For instance, the foundation tale of Our Lady of Alsemberg centers on interventions of a miraculous thread during every stage of the church's construction, but the creation of the sanctuary and the donation of the statue are attributed to St Elizabeth (fig. 5). ${ }^{33}$ The story begins with the apparition of an angel to the saint who exhorts her to build a church in honor of the Virgin in the Duchy of Brabant. Elizabeth addresses this request to Duchess Marie, the wife of Henry II, who would marry Sophie, Elizabeth's daughter, after Marie's death. The angel appears a second time to allay Elizabeth's doubts about the location of the church. He sends her to Alsemberg hill where she is to find a blooming flax field, ripened in one night, where the plan is traced

31. Kort begryp van Onse Lieve Vrouwe Ter Muylen te Liedekerke, Muylen, 1758; Bertholdus a S. Josepho, Een kort verhael vanden oorspronck, fundatie ende ovderdom, van het clooster onser L. Vrovwe ter Mvylen Ende hoe een nieuwe heremitagie ghesticht wort ter eeren vanden H. Ioseph, Ghent, Anthone Sersanders, 1653, p. 22-23.

32. Emile Henri Van Heurck, Les drapelets de pèlerinage en Belgique et dans les pays voisins: contribution à l'iconographie et à l'histoire des pèlerinages, Antwerp, Buschmann, 1922, p. 46-48.

33. L. Van Lathem, Histoire de la devote, p. 12-22. 
by means of the miraculous thread. The thread further guides the building works of St Elizabeth and her successors. In this case, the hybridity of the story helps to explain the fact that two essentially unrelated miraculous objects - the church building and the statue together establish a place of worship in Brabant.

Similarly, important personalities occasionally intervene in histories of statues marked by miraculous events. In some cases, this intervention occurs in a 'pre-history' of the image, a miraculous story that precedes the actual development of the cult, as it is the case for Our Lady of Good Success in Brussels. For six centuries the statue had been revered in Aberdeen, where it accomplished several miracles. When Protestantism reached Scotland, the image was miraculously preserved against iconoclasts. In his booklet on the cult, Bartholomaeus De Los Rios argues that the decline of the 'true faith' in Scotland justified the transfer of the miraculous image - and its worship - to a place where Catholic faith was still intact: the Southern Low Countries. ${ }^{34}$ Thanks to the intervention of an agent of the King of Spain, the statue was sent to De Los Rios and Archduchess Isabella, in Dunkirk, in 1625. Isabella moved it to her chapel in Brussels before De Los Rios suggested her to pledge it to the new church of the Augustinians in Brussels. Inside the Brabant area, Our Lady of 's-Hertogenbosch (Onze-LieveVrouw van 's-Hertogenbosch/Notre-Dame de Bois-le-Duc) was protected against protestant attacks for two centuries: venerated since 1381, the statue was transferred to Brussels after the siege of 's-Hertogenbosch in 1629. Received by the Archduchess Isabella, the miraculous image was displayed in St Gaugericus' Church, before Cardinal-Infante Ferdinand of Austria brought it back to St James' Church on the Coudenberg, next to the palace. ${ }^{35}$ The statue was returned to 's-Hertogenbosch in 1853. In one case, a pledge and

34. Bartholomaeus De Los Rios y Alarcón, Histoire de l'image miraculeuse de la Très-Sainte Vierge Marie, sous le titre de Notre-Dame de Bon Succes, Tournai, Louis Varle, 1726, p. 1-31.

35. Thomas Bernarts, Doux tronc de vigne distillant les miracles de N. Dame la Mere de Douceur premierement exposée à Bois-le-Ducq, Dans l'Eglise Cathedrale de Saint Jean, \& maintenant refugée à Bruxelles en l'Eglise des Chanoines Reguliers de Coberges, Brussels, Hubert Anthoine Velpius, 1665, p. 6-17, 243-254. See also Jean-Jacques Courvoisier, Le sacré bocage de Nostre Dame de Bois le Duc où par huict arbres \& plantes singulières, sont représentées en huict divines paralleles, les grandeurs \& les merveilles de la tres-saincte Vierge Marie, Mere de Dieu, Brussels, Godefroy Schoevarts, 1645; A. Wichmans, Brabantia Mariana, p. 369-383. 
subsequent miraculous intervention was said to precede the gift of a statue. Caught in a tempest in the Golf of Lyon, a Roman passenger prayed to Our Lady Stella Maris (Onze-Lieve-Vrouw Ster der Zee) for help and promised to promote her cult. Back in Rome, he commissioned a statue, which was given to Pope Urban VIII. Sometime later, Egide Houtmas, a Friar Minor of Boetendael, expressed the wish to honor Mary, Queen of Angels, and the pope sent him the statue in return. Thus, the history casts Our Lady of Angels (OnzeLieve-Vrouw ter Engelen) as a votive statue made after a miraculous intervention that acquired a respectable pedigree thanks to the involvement of the pope. ${ }^{36}$

\section{Historical aCCOUNTS AND MATERIAL SURROUNDINGS: GENERAL STRATEGIES}

The discussion of the historical accounts already indicates how they hint at the topographical, spatial and material aspects of the cult of miracle-working statues: some statues emphatically indicated their physical attachment to a specific locus, while others were housed in shrines designed by divine intervention. Still other statues were installed or found in humble surroundings that progressively transformed into sumptuous places of worship when the statues started performing miracles. The intervention of prominent patrons suggests the accretion of ornaments and gifts. In what follows, we examine in more detail the spatial and material context of the statues conjured up by the histories in miracle booklets, and relate it to the architecture and decoration of the shrines themselves in order to understand if and how the surroundings of the statues reflect the historical narratives. If the historical accounts anchor the statues - objects of divine origin or with divine powers - in time and space, and inscribe the statues in the history of a particular place and community, does their material context form part of this process and if so, how?

This step brings its own methodological challenges. The analysis of the historical accounts operated on the level of the narrative. Rather than gleaning historical information about the statues 
and their cult, we attempted to understand how these narratives explained the presence of a statue in a particular shrine. An enquiry into the material context of the statues introduces the question of the historical value of the accounts. As justifications of a particular cult at the time of their publication, the accounts are prone to referencing either previous material objects whose existence is often difficult to verify, or to casting contemporary material objects in accordance with the intentions behind the narrative rather than with historical facts. In other words, narrative and material contexts entertain various possible relationships, from a straightforward historical explanation of the present state of a shrine, to a complex reinterpretation of the shrine in line with the requirements of the narrative. ${ }^{37}$ Establishing this relationship is further complicated by the fact that, while historians of art and architecture have studied some altars, chapels and churches listed in the accounts, most have received little attention. Moreover, the immediate material surroundings of statues such as dresses, exhibition thrones, altars and church interiors often have undergone mainly undocumented changes since the $17^{\text {th }}$ century. ${ }^{38}$ This is also true for the statues themselves; it is often difficult to identify the exact object a historical account refers to, or to date and identify the statues that are still in place today. Finally, the particular circumstances surrounding the history of each shrine stretched the chronological limits of our inquiry: developments in the material surroundings that occurred over the course of decades in one case would take several centuries in others. Still, the developments remained similar, which is why we have opted to discuss transformations that have taken place well after the cusp of the $18^{\text {th }}$ century.

With these caveats in mind, we have proceeded to distinguish two sets of strategies that anchor the statues in time and space. One set

37. An example of this process is discussed in Maarten Delbeke, "Miracle books and religious architecture in the Southern Netherlands. The case of Our Lady of Hanswijk in Mechelen", The Authority of the Word. Reflecting on Image and Text in Northern Europe 1400-1700, ed. Walter Melion et al., Leiden, Brill, 2011, p. 559-585.

38. Important studies of these objects include the forthcoming studies of Valerie Herremans and Claire Baizier, as well as Paul Philippot et al., L'architecture religieuse et la sculpture baroques dans les Pays-Bas méridionaux et la principauté de Liège 1600-1770, Sprimont, Mardaga, 2003; Backlit Heaven. Power and Devotion in the Archdiocese Mechelen, ed. Gerard Rooijakkers and Paul Vandenbroeck, Tielt, Lannoo, 2009. 
occurs across a wide range of shrines and their histories, regardless of the type of account. Other strategies, we argue, are specific to the three types of scenarios that we have identified. In what follows, we offer a brief description of the general strategies and treat the typespecific variety in more detail.

At the most general level, the very publication of the $17^{\text {th }}$ century accounts we examine here contributes to anchoring the statues in history. Statues of very diverse pedigrees and provenances are made part of a history that has the late $16^{\text {th }}$, early $17^{\text {th }}$ century as its point of reference. The highly conventional nature of the accounts reinforces the effect of synchronicity. ${ }^{39}$ In the wake of the Beeldenstorm, numerous new statues were discovered and installed, such as Our Lady of Kortenbos, Minderhout, Zemst or Duffel. In other cases, newly built churches incorporated existing Marian cults. The new church of the Augustinians in Brussels, built by Jacques Franquart between 1620 and 1642, received in 1626 the Scottish image of Our Lady of Good Success. ${ }^{40}$ Still other cases vaunted the medieval origins of statues and cult sites of the Virgin. Mary's intervention in the construction of the shrines at Laken and Basse-Wavre goes back to the $9^{\text {th }}$ and $11^{\text {th }}$ centuries, whereas images in Alsemberg, Halle and Vilvoorde were gifted in the $13^{\text {th }}$ century by Saint Elizabeth and her descendants. The statues of Our Lady on the Stake (Onze-Lieve-Vrouw op 't Stocxken) and of Our Lady of Bois-Seigneur-Isaac were said to have been transferred to Brussels (Onze-Lieve-Vrouw van de Zavel) and Ittre (Onze-Lieve-Vrouw van Troost en Genade) in the $14^{\text {th }}$ century. In Leuven, in 1442, at the time of the construction of the new St Peter's Church, the Sedes sapientiae replaced an earlier statue. ${ }^{41}$ Whereas most of these statues eventually received a church entirely dedicated to them (Laken, Basse-Wavre,

39. On the role of "hagiographical wording" (including testimonies about miracles, stories of the cult origins, prayers, archives, etc.) in the cult of images, see Thomas Golsenne, "Parure et Culte", La performance des images, ed. Alain Dierkens, Gil Bartholeyns and Thomas Golsenne, Brussels, Éditions de l'université de Bruxelles ("Problèmes d'histoire des religions", 19), 2009, p. 80-82.

40. P. Philippot et al., L'architecture religieuse, p. 15; B. De Los Rios y Alarçon, Histoire de l'image miraculeuse, p. 14-22.

41. Raymond M. Lemaire et al., Le Patrimoine monumental de la Belgique, 1: Province de Brabant. Arrondissement de Louvain, Liège, Soledi, 1971, p. 216-221. 
Alsemberg, Zavel, etc.), others were housed in a part of a larger structure (Halle, Ittre, Leuven, etc.).

The $17^{\text {th }}$ century records of these histories formed part of a set of efforts to promote the cult of the Virgin in the Southern Netherlands in the aftermath of Protestant attacks. These efforts were supported by campaigns of construction, restoration and decoration of shrines. For instance, the Archdukes refurbished the medieval church of Our Lady of Laken and facilitated its access from the city of Brussels. ${ }^{42}$ However, interventions in Marian shrines were not confined to archducal or noble patronage, nor to large-scale architecture. In all cases, the statues are small and simple, and they were progressively surrounded with protective devices and ornaments. Their body disappeared under a cone-shaped dress, embroidered and decorated with necklaces. The statue was placed on a throne or inserted in a niche, often as part of a monumental altar. Located in the main choir or in a lateral chapel, the altar is more or less visible and accessible to believers entering the church, and may form part of an ensemble with other elements of the church furniture. Figurative representations, carved or painted, refer to the cult of the Virgin and her miraculous statue. Both isolated and integrated, masked and highlighted, the visibility of the statue is modified by these successive ornamental layers, whose richness and artistry seem to compensate for the inconspicuousness of the statue itself.

In some rare cases, these ornamental layers form a unity that was progressively developed over time. In the Our Lady of Kortenbos Church (fig. 6), built from 1641 onwards, the miraculous statue is placed on a monumental altar. An altarpiece by Gaspar de Crayer (1662), inserted in the current altar completed in 1710 by Pieter Scheemaeckers, represents St Norbertus kneeling besides the Virgin, interceding for the needy crowded around them. The choir is enclosed

42. According to Q. Hennin, Origine de l'église miraculeuse de Lacq, p. 23, the Archdukes commissioned a stained glass window above the main entrance depicting the story, with a dedication dated 1601. According to A. Delfosse, La "Protectrice du Païs-Bas", p. 117: in 1602, Nicolas Mertens, master glass artist from Brussels, was paid for making a double stained glass window, presenting the Archdukes and the Virgin of Seven Sorrows. On the planning of the access roads around the church, see Krista De Jonge and Annemie De Vos, "Architectuur ten tijde van de aartshertogen: het hof achterna", Bellissimi ingegni, grandissimo splendore. Studies over de religieuze architectuur in de Zuidelijke Nederlanden tijdens de 17de eeuw, ed. Krista De Jonge, Annemie De Vos and Joris Snaet, Leuven, Universitaire Pers Leuven, 2000, p. 11-42, here p. 36-37. A. Delfosse, La "Protectrice du Païs-Bas", p. 118-119. 
with an oak communion rail (ca. 1724) engraved with the monograms of the Virgin, which are placed between the coats of arms of both Stephanus vander Steghen, abbot of Averbode, and the Van Kerckhem family, lords of the land. The balustrade of the transept is decked out with panels where inscriptions relate the miraculous healing in Kortenbos, miracles approved by Jan de Chokier, vicar-general of the Liège bishopric. ${ }^{43}$ Along with votive paintings and portraits of Norbertine saints, hung in the nave, the display of the choir emphasizes the nature of the cult, supported by different administrators - representatives from either the bishopric of Liège or the Premonstratensian order and beneficiaries - miraculously healed people among the secular and religious population.

Yet far more often, rather than commanding a purpose-built church interior, statues would receive an altar or a throne. This is the case, for instance, in the Church of Our Lady of Aarschot, built in the late $14^{\text {th }}$ and early $15^{\text {th }}$ century, where Pieter Scheemaeckers de Oude realized, in 1684, a set of three lateral altars, dedicated to the Virgin, the Blessed Sacrament and St Joseph. ${ }^{44}$ A spectacular example is the altar designed by Lucas Faydherbe in 1658 for the Sedes Sapientiae in Leuven. ${ }^{45}$ In miracle booklets dedicated to Our Lady of Leuven, this altar is illustrated and described in exceptional detail (fig. 7). ${ }^{46}$ When the statue lacked permanent accommodation, the accounts emphasize that lavish ephemeral displays were set up. This is the case of Our Lady of Vilvoorde, which is carried along by the community of Carmelite nuns seeking shelter from attacks by heretics in town after town. ${ }^{47}$ Some texts single out the interior decorations of churches as a particular attribute of the statue.

43. Suzanne Van Aerschot - Van Haeverbeeck, Bouwen door de eeuwen heen. Inventaris van het cultuurbezit in België. Architectuur, 6n2: Provincie Limburg. Arrondissement Hasselt, Ghent, Snoeck-Ducapi \& Zoon, 1981, p. 829-831; Trudo Jan Gerits, Mariale basiliek van Kortenbos, Hasselt, Sint-Quintinus-drukk., 1973 , p. 11-14; P. Philippot et. al., L'architecture religieuse, p. 424. The church was built between 1641 and 1648, the transept between 1655 and 1665; the tower was only completed in 1725 . The cabin and tree holding the statue were destroyed when the church was built.

44. R. Lemaire, Le patrimoine monumental de la Belgique, 1, p. 14-16; P. Philippot et al., L'architecture religieuse, p. 414-415.

45. M. G. Vander Buecken, Wonderen bystandt, p. 37.

46. B. Heymbach, Diva Lovaniensis, p. 5-8; M. G. Vander Buecken, Wonderen bystandt, p. 40-42

47. J. Compaignom, Histoire de l'image admirable, p. 37, 44, 59, 61-62, 78, 101-103, 120-21, 126. 
Bartholomeus De Los Rios stressed that Isabella spared nothing to adorn the new Brussels church of the Augustinians, destined to receive the statue of Onze-Lieve-Vrouw van Goed Succes. She decorated the church interior with her own hands "in such a noble and rich manner, that jewels of great value, shining all over the place, could be seen with admiration". ${ }^{48}$

In numerous texts, terms of 'brilliance' do not simply describe precious elements surrounding the statue, but characterize manifestations of the divine as well as the devotion of worshippers. When heretics attacked the monastery of Carmelite nuns in Vilvoorde, they were halted in their tracks at the view of "another exceptionally beautiful woman, whiter than lily flowers, more gleaming than the sun, decorated and adorned with a marvelous white cloth". ${ }^{49}$ If the 'whiteness' of Mary's apparition stunned the assailants, the 'bright' presentation of the statue seems to play its part in devotional practices: covered with a white veil or clothed with a crown and dress of gold,$^{50}$ the image is taken in procession or displayed on an altar, "decorated and adorned by lights". ${ }^{51}$ In Brussels, numerous visitors would pay homage to the Vilvoorde statue "whose sparkling and admirable splendor proceeding from it stimulated them to greater devotion towards the Virgin". ${ }^{52}$ In Basse-Wavre, the story of the miraculous foundation is punctuated with 'sparkles'. The apparition of the Virgin is preceded by celestial chants, angelic music and sparkling of lights, which seduce the ears and dazzle the eyes of the witnesses, stirring up tears of contrition and devotion. ${ }^{53}$ When the 'Queen of Heaven' appeared to the priests, amidst shining lights, she declared in a clear voice: "Hanc vallem inhabitabo, quoniam elegi eam" (fig. 2) ${ }^{54}$. The iconography of the statue rehearses these brilliant and resounding components,

48. B. De Los Rios y Alarcón, Histoire de l'image miraculeuse, p. 15: "Elle orna de ses propres mains la $\mathrm{S}$. Image, mais d'une manière si noble et si riche, que l'on voyait avec admiration des joyaux de grands prix y briller de toute part".

49. J. Compaignom, Histoire de l'image admirable, p. 67-68: "une autre Femme belle par excellence, plus blanche que les fleurs de lis, plus reluisante que le Soleil, ornée \& parée d'un vêtement blanc à merveille".

50. Ibid., p. 101-102, 106, 120-121.

51. Ibid., p. 101-102.

52. Ibid., p. 102: "dont l'esclat \& splendeur admirable qui en procedoit les excitoit à plus grande devotion envers la Vierge".

53. L'arche d'Alliance, p. 9-11.

54. Ibid, p. 15-16. 
for instance in an engraving inserted in a miracle booklet, where the famous verse is written in a phylactery descending from a radiant Madonna with Child (fig. 8). By replacing the actual statue with this vibrant apparition, hovering above the altar of the holy shrine, the illustration relates the chapel to its divine origin as well as to its devotional purpose.

Sparkles of the divine sanctify the otherwise often desolate or uncultivated places the Virgin elects for her worship. Authors of miracle books often debate this divine choice, as they seek to assert the legitimacy of the divine decision with arguments drawn from local history and biblical texts. Several accounts stress that, besides trees or fields, the Virgin prefers desolate places such as swamps (Basse-Wavre, Tienen, Laken) or 'wild and isolated' sites (Kortenbos, Welriecken), so that she can display all her power by transforming them into 'heaven'. ${ }^{55}$ When cities in the flourishing Duchy of Brabant such as Halle or Vilvoorde were 'elected' to receive a statue, they too gained much prestige from the sanctity of their shrines and the benefits the Virgin granted them. ${ }^{56}$

In many cases, the choice of location instigates what could be termed an 'anchoring' of the statue in its place of worship. This phenomenon is most manifest when a statue or its means of transportation are immobilized, or when a statue is associated with natural elements such as trees and sources, rendering them seemingly age-old and natural. ${ }^{57}$ Miraculous foundations push this principle to the extreme, as divine intervention not only dictates the location but also the design of the sanctuary. In these cases, the anchoring of the building itself brings out the relative mobility of the miraculous object. The shrine of Basse-Wavre, for instance, owes its reputation to the miracles that are accomplished when it is transferred to Brussels or carried in processions in neighboring

55. For example, Ibid., p. 7, 12-14: situated close to Wavre, one of the "belles villes" of the powerful Brabant, Basse-Wavre is first characterized as a place of brambles and dead waters. Therefore, the destruction and reconstruction of the church are viewed as evidences of God's will to "changer ce lieu inhabitable en un paradis de délice".

56. For example J. Lipsius, La Nostre Dame de Hau, p. 17; J. Compaignom, Histoire de l'image admirable, p. 50-51.

57. Alexandra Walsham, The Reformation of the Landscape. Religion, Identity, \& Memory in Early Modern Britain \& Ireland, Oxford, Oxford University Press, 2011, p. 156-189. 
towns and villages. ${ }^{58}$ But the shrine is only effective if it is returned to Basse-Wavre. This principle is illustrated by an incident at $\mathrm{St}$ Nicholas' Church in Brussels: the abbot of Afflighem tried in vain to lift the reliquary to bring it to his abbey, but the prior of BasseWavre took it without effort. ${ }^{59}$

The movement of the image is thus granted only for specific occasions and circumstances. In some cases, this 'authorized mobility' leads to a permanent transfer of a statue from one place to another. This is the case, for example, with Our Lady of Hanswijk, a statue that chose its place of worship in the periphery of Mechelen through immobilization, only to become the protector of the city once it was moved inside the city walls. ${ }^{60}$ This transfer was subsequently ritualized in processions, which helped to represent and circumscribe the statue's sphere of action. Processions also helped to forge a relationship between the statue and a particular community of worshippers and delineate a 'sacred space' visible to the devotees and even more so to those opposing the church (fig. 9). ${ }^{61}$ The community could consist of the local parish, nobility or clergy, and in several cases - such as Our Lady of Good Will (Onze-Lieve-Vrouw van Goede Wil) in Duffel - the statue was the object of conflicting claims. ${ }^{62}$

Yet, a statue often only became active once a relationship with a community was established. The cult at Wolvertem had existed since 1658, but it began to flourish when, at the end of the century, the local priest De Munck incorporated it in the parish network. ${ }^{63}$ Noble patronage initiated the cult in Havré, and under the impetus of the family de Croÿ a cult was established in Aarschot. Antoon de Croÿ and his wife Margaretha van Lorreinen founded in 1462 a chapter to serve at the church, where the statue of Our Lady of Aarschot was venerated. According to the accounts of Wichmans,

58. L'arche d'Alliance, p. 14-29, 46-66, 216-223.

59. Ibid., p. 29-35.

60. M. Delbeke, "Miracle books and religious architecture", p. 559-585.

61. Cf. Infra, p. 20.

62. Anneleen Perneel, "Onze-Lieve-Vrouw van Goede Wil te Duffel, een verhaal als (g)een ander? De impact van het Concilie van Trente op de Zuidelijke Nederlanden in de zeventiende eeuw", Trajecta, 18, 4, 2009, p. 345-365, here p. 348-353.

63. Jacques 't Kint, De devotie tot Onze Lieve Vrouw Behoudenis der Kranken en de Boskapel te Wolvertem Drie Eeuwen Geschiedenis 1658-1958, Wolvertem, Troost, 1958, p. 13-16. 
De Reume and others, the image belonged to the same network as the Hanswijk statue and the Virgin venerated at Werchter. ${ }^{64}$ In Wolvertem, the family Turn and Taxis had their escutcheon attached above the entrance of the chapel.$^{65}$ The shrines in question were often votive chapels, sometimes built before the advent of a miraculous statue, as happened in Ittre, Liedekerke and Wever. With regard to the clergy, new religious orders often adopted and propagated existing cults. In Liedekerke, a Carmelite cloister was built next to the Marian chapel. ${ }^{66}$ The Norbertines supported new cults in Amelgem, Duffel, Jezus-Eik, Minderhout and Retie. ${ }^{67}$

\section{Historical ACCOUNTS AND MATERIAL SURROUNDINGS: THREE TYPES}

Besides the general strategies, some characteristics of the material surroundings of miraculous statues seem specific to each type of narrative. Regarding the architecture of the shrines, it appears that the third type of accounts - where the statue itself is the object or the agent of founding miracles - often involves small shrines of local importance, while sanctuaries associated with the first two types are more often large-scale churches. Their exceptional importance calls for legitimization, which is found in the alleged miraculous foundation or the long and prestigious patronage of the shrine. In these cases, the decoration and iconography reinforced the anchoring of the statue to the sanctuary already suggested in the miracle booklets. The other cases, linked to the third type of accounts, have a particular logic of their own.

Since the miraculous foundation of the church building is at the center of the first type of account, the building itself acts as a material witness to its own history. For example, among the

64. A. Wichmans, Brabantia Mariana, Libr. II, Cap. LIv; A.-J. de Reume, Les vierges miraculeuses, p. 267-268.

65. J. 't Kint, De devotie tot Onze Lieve Vrouw, p. 20.

66. Een kort verhael vanden oorspronck, fundatie ende overdom, Van het Oudt eertijts vermaert Clooster Onser L. Vrouwe ter Muylen, vanden orden der Carmeliten Gelegen inden boschende heerlijckheyt van Liedekercke. Ende hoe op de selve plaetse een nieuwe Heremitagie ghesticht wort ter eeren vanden $H$. Joseph, Ghent, Anthone Sersanders, 1653, p. 22-30.

67. Frans J. M. Hoppenbrouwers, "Franciscus Augustinus Wichmans (1596-1661). Kanunnik, zielzorger en abt van Tongerlo ten tijde van de vroege Katholieke Reformatie (vervolg)", Analecta, 71, 1995, p. 96-149, here p. 126. 
engravings illustrating the story of Our Lady of Laken, one in particular summarizes the divine origin of the building. It shows the thread in a small container, displayed in front of a model of the church presented by two angels (fig. 10). Preserved as a relic, this first miraculous object was also said to relieve pregnant women. ${ }^{68}$ On the contrary, the origin of the Our Lady statue kept in the church is not specified in the history. Still, its ritual use fits with the justification of the southern orientation of the church brought about by the miraculous thread, for both the actions of the statue and the orientation of the church bear witness to the Virgin's desire to protect Brussels. The image was taken in procession to the city to stop floods and droughts. ${ }^{69}$ This peculiar relationship between the Virgin and the city was further materialized by means of urban planning in 1625, when the Archdukes ordered Jacques Franquart to design a path joining the city gates to the place of worship. ${ }^{70}$

Contrary to the first type of account, the second type usually does not focus on the miraculous origin of the church, but on the notion of the gift: first the donation of the image, then of various gifts or ex-votos from pilgrims and sovereigns. While some gifts contribute to building the church, others are artifacts to be placed inside the chapel. Sumptuous examples of this practice are the statues, liturgical objects, lamps and dresses surrounding the statue of Halle, described by Lipsius and depicted in engravings (fig. 11). ${ }^{71}$ In his story of Our Lady of Vilvoorde, Compaignom introduces St Elizabeth's gift of the images by defining the four possible values of donations: "whether they are made for renowned or saint persons, or presented to someone of quality or high dignity; whether they are of great value, or they bring profit or are of use". ${ }^{72}$ The following chapters intend to prove that the image of 'Onze-Lieve-Vrouw van Troost' perfectly matches these criteria, because of the prestigious lineage or the moral virtues of the persons related to the donation (fig. 3) - St Elizabeth, Princess Sophie, Beguines, then Carmelite

68. Q. Hennin, Origine de l'église miraculeuse de Lacq, p. 80-81.

69. Ibid., p. 37-40.

70. Ibid., p. 85-88.

71. J. Lipsius, La Nostre Dame de Hau, p. 106-117.

72. J. Compaignom, Histoire de l'image admirable, p. 34: "s'ils sont faits pour personnes illustres ou saincte, ou presentez à quelqu'un de qualité ou dignité relevée: s'ils sont de grande valeur, ou portent du profit \& utilité". 
Nuns - as well as the numerous good deeds that happened during the peregrinations of the precious statue.

Often, the interior decoration of the church serves to visualize the history and pedigree of the statue, as in the Our Lady of Alsemberg Church. In the nave, a painted cycle by Antoon Sallaert, from 1645-1650, depicts six moments of the legend, including the call to St Elizabeth, where two angels offer her the thread and a view of the elevation of the church (fig. 5). ${ }^{73}$ A seventh painting represents the writers who relayed the miraculous story since the $15^{\text {th }}$ century, kneeling in front of the Our Lady statue (fig. 12) ${ }^{74}$ The painted cycle thus associates the present aspect of the church with the intentions of the Virgin, while emphasizing how the written tradition supports the cult of the image. At the same time, the church building itself is presented as a guarantee of the veracity of this tradition. According to Van Lathem, it "is corroborated by very ancient paintings on the Church's stained glasses windows, where part of this story can still be seen". ${ }^{75}$ In the absence of written sources about every miracle that happened in Alsemberg, the church itself is marshaled as a testimony of the divine interventions, "which the building and the stones of the church themselves cry out loud". ${ }^{76}$ Yet the author also emphasizes the involvement of generations of sovereigns who contributed to the construction of the windows and vaults of the church. ${ }^{77}$ Today, apart from the "coats of arms" of these princes, mentioned by Van Lathem, the church keeps a series of portraits of the sovereigns that contributed to the development of the Alsemberg sanctuary, from

73. Angels are sent to St Elizabeth telling her to build a church; angels bring an elevation of the church to St Elizabeth; St Elizabeth visits Marie's, Duchess of Brabant; an angel appears to three sisters; the next morning, the sisters find their flax field ripe; Duke Jan III reprimanded by the Virgin. See Constant Theys, Geschiedenis van Alsemberg, Brussels, A. Hessens, 1960, p. 393-399.

74. Prior J. Gillemans (vice prior of 't Roode-cloister), abbot C. Vranx (abbot of 't St Peters-cloister, Ghent), priest F. van Rosweide (Jesuit), abbot A. Wichmans (abbot of Tongerlo), and pastor J.B. Van Lathem (pastor of Alsemberg). Van Lathem quoted most of these writers as sources for his account on Our Lady of Alsemberg: see L. Van Lathem, Histoire de la devote, p 11-12.

75. Ibid., p. 10: "se confirme par de très-anciennes peintures dans les verriers de l'Eglise, où l'on voit encore une partie de cette histoire".

76. Ibid., p. 32: "ce que le bâtiment \& les pierres mêmes de l'Eglise disent à grande voix".

77. Ibid., p. 24-28: windows were gifted by Antoine of Burgundy (ca. 1395), Philip the Good (ca. 1455) and emperor Maximilian (1514), while Charles the Bold (ca. 1470) and Charles V (1520) have contributed to the vault of the choir. 
St Elizabeth to Maria Elizabeth of Austria (fig. 13). ${ }^{78}$ The hybridity of the Alsemberg story, which combines divine agency and human patronage, is expressed in the interplay between historiographical text, sacred and secular iconography, and architectural environment.

The accounts of the third type vary considerably. Still, these stories share a concerted attention for the historical development of the place of worship, which finds its reflection in a particular building strategy. The architecture of the shrines of statues described in the third type of narratives develops according to a fixed sequence of at most six stages. The miracle books describe these stages, and they are often visualized in paintings and other representations. They can be traced in the building history of the sanctuaries as well. Just like the narratives, the building stages reveal common characteristics that are adapted to the specificity of each case. In general terms, the sequence corresponds with a process of 'organic growth'. A selection of cases will illustrate this process.

In more than half of the cases where the statue itself is the miracleworking object establishing the place of worship, it is initially found or placed in a tree..$^{79}$ Consequently, the tree is the first material context of the statue. Often the statue is sheltered and secured to the tree by means of a little wooden cabinet or an expanded cavity. Sometimes a lantern is installed. The account of Our Lady of Good Will in Duffel, for example, claims that neighbors enlarged the cavity in the willow where the statue was found, in order to protect it from the rain and to light it with a lantern. ${ }^{80}$ The primitive accommodation of a statue in a tree is frequently depicted on the

78. Four groups of four paintings, currently preserved in the paneling of the sacristy, represent St Elizabeth, Sophie and Henry II of Brabant, John III of Brabant; Antoine of Burgundy, Philip the Good, Charles the Bold and Mary of Burgundy; Maximilian I, Margaret of Austria, Charles V and Philip II; Archdukes Albert and Isabella, Leopold Wilhelm and Maria Elizabeth of Austria. Nine of these portraits $\left(7^{\text {th }}\right.$ to $\left.15^{\text {th }}\right)$ would have been painted by Antoon Sallaert before 1657, while the $16^{\text {th }}$ was painted after 1732. See Theys, Geschiedenis, p. 349-352.

79. Ratio based on the number of cases that we have selected, as indicated in the introduction.

80. Philippus Van Hoeswinckel, Onse L.Vrouwe van Duffel dat is den oorspronck, voortganck ende miraculen van haer miraculeus beelt gevonden binnen de baenderye van duffel onder perwez. Den 14. Aug. $A^{\circ} 1637$, Antwerp, Martinus Binnaert, 1644, p. 38-39; Norbertus Mattens, Onse L. Vrouwe van Duffel ofte van goeden wil. Dat is de wonderheden van Maria, soo in het doen vinden ende hervinden van haer miraculeus beeldt als in $t$ gunstig uytstorten van wonderbare genesingen tot Duffel, Antwerp, de Weduwe Jacobs, 1717, p. 16. 
frontispiece of miracle books (fig. 4) and pennons. A painting in the present Church of Our Lady of Jezus-Eik depicts the 'little chapel' made for the statue: a cabinet resembling a bird box, which is said to be preserved in the presbytery (fig. 14). ${ }^{81}$

When the cult develops, the statue is removed from the tree and placed on a pillar: a cemented column erected on a square floor plan. The statue is housed in a little cabinet with an open or glazed front and a small gabled roof. These simple constructions are reminiscent of the initial tree. This second phase of the scheme is, for instance, illustrated in the stained glass windows at the Our Lady in the Field Chapel in Minderhout, where the history of the image is displayed. Hagelberg chapel in Berendrecht still preserves the original pillar, dating from 1732 (fig. 15). The surface of the column base is less than one square meter $(0.86 \mathrm{~m} \times 0.86 \mathrm{~m})$, while the original pillar (including the top of the cross crowning the turret) must have been approximately seven meters high. Today the pillar rises about three meters above the floor level of the choir that was built around the column..$^{82}$

In a third building stage, a wooden chapel is built. It no longer houses only the statue but also shelters worshippers. Made of wood, these chapels were soon replaced by stone chapels. As a consequence, this stage is documented only in miracle books and some paintings and drawings. In the case of Our Lady of Good Will in Duffel, the wooden chapel, a small construction protecting both statue and pilgrims, was built immediately after the tree was adapted to shelter the statue. ${ }^{83}$ The willow and the statue were enclosed in the chapel, preserving their original connection. In Jezus-Eik (fig. 16) or Wolvertem, too, a wooden chapel was built. ${ }^{84}$

The stone chapels that soon replaced the wooden cabins over the course of the $17^{\text {th }}$ century were often built from bricks. The plan could be centralized or rectangular, with a single aisle. Centralized plans encompass cruciform, hexagonal or octagonal schemes. Initially

81. B. Seghers, Den pelgrim van Sonien-Bosch, p. 25-26; Het devote erfgoed van Jezus-Eik, Jezus-Eik, Dorpsraad, 2007, p. 3.

82. G. Geerts, "De kapel van de Hagelberg te Berendrecht", p. 27.

83. N. Mattens, Onse L. Vrouwe van Duffel, p. 17.

84. For Jezus-Eik, see B. Seghers, Den pelgrim van Sonien-Bosch, p. 30-31; For Wolvertem, see S. Schoutens. Maria's Brabant, p. 204. 
Duffel and Minderhout, both supported by the Premonstratensians (or Norbertines), followed a cruciform plan. In the case of Duffel, the altar of the first stone chapel was placed on the original spot of the tree, and it would have contained a piece of the willow where the statue was found (fig. 17a). ${ }^{85}$ Also, in the case of the Our Lady in the Field in Minderhout, built in 1650, the second chapel was on the same spot as the first shrine (fig. 17b). ${ }^{86}$ The Norbertines built another centralized chapel in Retie. The Our Lady in the Snow (Onze-LieveVrouw ter Sneeuw) has an octagonal ground plan and was erected in 1665 to replace the wooden chapel of 1646 (fig. 17c). ${ }^{87}$ The octagonal scheme is also found at the Our Lady of Fever (Onze-Lieve-Vrouw ter Koorts) in Leuven and at the chapel of the Cistercian abbey in Villers-la-Ville from 1613. ${ }^{88}$ The plans for the churches of Our Lady of Consolation, part of the Carmelite cloister in Vilvoorde, and of Our Lady of Good Support (Onze-Lieve-Vrouw van Goede Bijstand) in Brussels are both based on hexagons, still visible in the present buildings. With the exception of the chapel in Villers-la-Ville, all of these polygons replaced an earlier chapel.

Yet most of these basic Marian chapels of the third type have a simple, generic plan: a single rectangular nave abutting a threesided apse. The length of the shrines ranges from one to three bays, and height and total surface vary significantly. The interior is mostly simple and unadorned. Inside the present Chapel of Our Lady of the Heinkensberg in Wever, a small stone chapel stands in the center of the ambulatory. The interior surface is no more than two square meters. Pennons and devotional images, illustrating the development of the sanctuary, suggest that this is a remnant of the first stone chapel built in 1572 (fig. 18a). In 1966 the decayed chapel was rebuilt, but the small chapel with the statue was retained and renovated, with an apparently original simple interior and a new

85. Ph. Van Hoeswinckel, Onse L.Vrouwe van Duffel, p. 40-45; N. Mattens, Onse L. Vrouwe van Duffel, p. 32.

86. J. Heylaerts, Beknopte geschiedenis, p. 18.

87. Hilde Kennes and Rita Steyaert, Bouwen door de eeuwen heen. Inventaris van het cultuurbezit in België. Architectuur, 16n3: Provincie Antwerpen. Arrondissement Turnhout. Kanton Herentals, Turnhout, Brepols, 2001, p. 379.

88. For Leuven, see Nood zoekt troost: de Vleminckx-kapel in de Vlamingenstraat te Leuven en het mirakuleus beeld Onze-Lieve-Vrouw-terKoorts, Vaalbeek, Pro arte christiana, p. 4; for Villers-la-Ville, see J. Snaet, "For the Greater Glory of God", p. 294. 
masonry cladding on the exterior. ${ }^{89}$ Similar freestanding remnants of small single-nave chapels can be found in Heffen, where the chapel for Our Lady in the Thorns (Onze-Lieve-Vrouw Ten Doorn) from 1643 stands on a raised terrace to protect it against floods (fig. 18e); in Amelgem, a two-bayed chapel from 1637 dedicated to Our Lady of Birth (Onze-Lieve-Vrouw-Geboorte) (fig. 18f); in Havré, at the Chapel of Our Lady of Good Will (Notre-Dame de Bon-Vouloir) dated from 1625; in Oud-Heverlee, where the chapel from 1651 with three bays replaced the old wooden chapel to honor Our Lady of Heap (Onze-Lieve-Vrouw van Steenbergen) (fig. 18g); and in Herentals, with a four-bay chapel built in 1667 for Our Lady in the Sand (Onze-Lieve-Vrouw in't Zand).$^{90}$

For many sanctuaries, the small stone chapel is the last stage of the development. In other cases, the simple stone chapel was retained and extended slightly in length. In Zemst, Wolvertem and Braine-le-Château, there are small chapels that fit this scheme. They were erected in 1669 to honor Our Lady in the Bend (Onze-LieveVrouw in het Hammeken) (fig. 18b), shortly after 1698 for Our Lady in the Woods (Onze-Lieve-Vrouw in den Bos) (fig. 18c) and probably in 1730 for Our Lady of Mercy (Onze-Lieve-Vrouw van Barmhartigheid). ${ }^{91}$ In the case of Berendrecht, in 1734, the chapel was literally built around the statue and its pillar (fig. 18d) ${ }^{92}$

In general, the first four stages in the development of the chapels succeed each other rapidly - in most cases, over the course of the $17^{\text {th }}$ century. Once the first stone building is erected, the process generally slows down. Further development of the shrine is dictated by circumstances such as the popularity of the cult - in some cases,

89. Wever, Heinkensberg, accessed November 27, 2014, http://www.glabbeek .be/website/14-www/24-www/584-www/589-www.html.

90. For Heffen, see Hilde Kennes, Greet Plomteux and Rita Steyaert, Bouwen door de eeuwen heen. Inventaris van het cultuurbezit in België. Architectuur, 13n2: Provincie Antwerpen. Arrondissement Mechelen. Kanton Mechelen, Turnhout, Brepols, 1995, p. 142-143; for Amelgem, see Christiane De Maegd and Suzanne Van Aerschot, Bouwen door de eeuwen heen. Inventaris van het cultuurbezit in België. Architectuur, 2n: Vlaams-Brabant. Halle-Vilvoorde, Gent, Snoeck-Ducaju, 1975, p. 82; for Havré, see Pierre Vanderlinden, La chapelle de Notre-Dame du bon vouloir à Havré-Mons, Mons, n. p., 1982; for Oud-Heverlee, see A.-J. de Reume, Les vierges miraculeuses, p. 423-424; for Herentals, see H. Kennes and R. Steyaert, Bouwen door de eeuwen heen, 16n3, p. 142-143.

91. For Zemst, Wolvertem and Braine-le-Château, see S. Schoutens, Maria's Brabant, p. 160, 204 and 32.

92. G. Geerts, "De kapel van de Hagelberg te Berendrecht", p 27. 
it is only in the $20^{\text {th }}$ century that a cult is vital enough to requisite an extended shrine. More often than not, the latter stages are not described in the miracle booklets.

In some cases, the chapels go through a fifth stage, when they are fundamentally transformed to enlarge them. The original stone chapel becomes the apse or sacristy of the new sanctuary, securing the attachment of the building to the original site. In most cases, the extension consists of a widened and enlarged nave, a simple structure with a gabled roof on a rectangular, single aisled ground plan placed on the axis of the existing chapel. The pennon of the Our Lady of the Heinkensberg of Wever clearly illustrates how, in 1900, the little chapel dating from 1572 was extended with a nave (fig. 19) and the original chapel became a miniscule apse (fig. 18h). ${ }^{93} \mathrm{~A}$ similar extension occurred in Berendrecht as late as 1925, whereas the façade and the first bay of the chapel of the Hagelberg (1734) were torn down to make room for a larger one-aisled rectangular nave. In addition, a sacristy was added (fig. 18k). ${ }^{94}$ At an unknown date, possibly in 1740, a nave was added to the Chapel of Our Lady of Mercy of Braine-le-Château. Here, the process of organic growth is articulated in the subsequent addition, in two successive building phases, of the small, three-sided apse and the larger rectangular nave. ${ }^{95}$ The small chapel for Our Lady in the Woods in Wolvertem from 1695 is an example where the first stone chapel became the sacristy of the new sanctuary. In this case, the extension, built only twelve years after the first construction, consists of a single-aisled rectangular nave with an elongated oval apse (fig. 18j).$^{96}$ In contrast, the sanctuary in Zemst was enlarged in 1699 with the addition of just one bay to the nave (fig. 18i). ${ }^{97}$

93. As mentioned above, this chapel was destroyed and rebuilt in 1966. The schematic plan illustrated here is based on the present chapel with a nave of three bays and an entrance on the short side of the nave opposite the apse. Representations of the original building on pennons and devotional leaflets suggest that before 1966 the entrance of the church was on the side, between two windows; still, the shape and proportions of the rectangular nave topped with a gable roof must have been comparable with the present construction of three bays.

94. G. Geerts, "De kapel van de Hagelberg te Berendrecht", p. 31-33.

95. E. H. Van Heurck, Les drapelets de pèlerinage en Belgique, p. 60; H. Maho, La Belgique à Marie, p. 61.

96. Ch. De Maegd and S. Van Aerschot, Bouwen door de eeuwen heen, 2n, p. 783.

97. Ibid., p. 808. 
Similar extensions occur in centralized chapels with a cruciform ground plan. As described in the miracle book of Heylaerts, in Minderhout, the nave of the chapel built in 1650 was lengthened already in 1686 . Heylaerts emphasizes that the unsurpassed popularity of the cult necessitated the extension. The priest, Hieronymus van Diependaal, received permission from the bishop of Antwerp to extend the chapel by "twentyone foot to the west". ${ }^{98}$ In 1688 , the nave was further extended and terminated with a new facade (fig. 17e). The same occurs at the sanctuary of the Our Lady of Good Will in Duffel. Between 1639 and 1642, four bays were added to the original cruciform plan inscribed in a square. This operation generated a twoaisled nave and a new portico marking the entrance (fig. 17d). ${ }^{99}$ Centralized chapels on a hexagonal or octagonal ground plan inscribed in a circle are generally not expanded, as they were quite large to begin with, except for the Our Lady of Fever in Leuven, finished only in 1705 and raised in height in $1732 .{ }^{100} \mathrm{In}$ Retie, a rectangular apse and sacristy were added to the octagonal plan (fig. 17f). ${ }^{101}$

Finally, in a sixth stage, a second extension is, in some cases, realized by building an ambulatory around the first chapel. This is again illustrated by the Our Lady of the Heinkensberg in Wever (fig. 181). An illustration on a pennon suggests that a three-sided ambulatory was built around the chapel in 1922 (fig. 19). This strategy not only preserves the original chapel, but also maintains the statue at the center of the church. ${ }^{102}$ Representations of the original Marian chapel in Lubbeek, on a pennon and a painting by François Xavier Joseph Jacquin from 1810, suggest a similar evolution. The chapel is depicted with a rectangular nave, with the entrance on the side and an elevated three-sided ambulatory. If Lubbeek follows the pattern of comparable cases,

98. J. Heylaerts, Beknopte geschiedenis, p. 21-22.

99. Hilde Kennes, Rita Steyaert and Suzanne Van Aerschot, Bouwen door de eeuwen heen. Inventaris van het cultuurbezit in België. Architectuur. 13n4: Provincie Antwerpen. Arrondissement Mechelen. Kantons Duffel, Heist-op-denBerg, Turnhout, Brepols, 1997, p. 61-63.

100. Nood zoekt troost, p. 4

101. H. Kennes and R. Steyaert, Bouwen door de eeuwen heen, 16n3, p. 379.

102. Wever,Heinkensberg, accessedNovember27,2014,http://www.glabbeek.be/ website/14-www/24-www/584-www/589-www.html. 
the rectangular nave extended the first chapel, which must have been built in 1275 . The ambulatory probably dates from 1341 and contains most likely the original chapel. ${ }^{103}$ The second extension of the chapel in Minderhout dates from 1691 and consists of a trilateral apse attached to an arm of the original cross. This transformation determines the final design of the interior. At the same time, both a sacristy and confessional were added to the north side of the building. The sanctuary of the Our Lady in the Field in Minderhout is exceptional because several volumes were added to the chapel in 1694, 1696 and 1745, respectively the portico, a second confessional and a sacristy on the southern side (fig. $17 \mathrm{~g}$ ). ${ }^{104}$

Throughout the six stages, the point of reference is the statue. The focal point of the original cult remains the physical center of the sanctuary. In its successive stages, the material surroundings are almost literally built around the image; in fact, even regardless of whether the statue is still in its original place, the architecture contrives to suggest so. The central position of the statue illustrates the extent to which the devotional practice is anchored to the place of origin. Besides encapsulating the spot where the statue was believed to be found or placed, the chapels also retain the memory of their origin by means of decorative elements. In Minderhout, the ceiling of the chapel carries floral motifs that rehearse the aspect of the original site, just like the references to the lime tree in Havré, or the tree sculpted on the altar in Heffen. ${ }^{105}$ The piece of the oak kept under the shrine in Jezus-Eik also links back to the myth of origin. ${ }^{106}$

103. As a consequence of the French revolution, the entire construction was destroyed in 1816. In 1891 a new chapel with a different design was built on the other side of the road. M. J. Celis and L. Spinnael, Onze Lieve Vrouw van Lubbeek in Brabant, Louvain, Paters Assumptionisten, 1960, p. 18-65.

104. Sibylle De Sadeleer and Greet Plomteux, Bouwen door de eeuwen heen. Inventaris van het cultuurbezit in België. Architectuur. 16n4: Provincie Antwerpen. Arrondissement Turnhout. Kanton Hoogstraten, Turnhout, Brepols, 2002, p. 258-261.

105. For other examples of this practice, see Albert Walzer, "Wallfahrtskirchen mit eingebauten Baum", Württembergisches Jahrbuch für Volkskunde, 1955, p. 90-116.

106. Het devote erfgoed van Jezus-Eik, p. 20. 


\section{Marian devotion ANd architecture in the Southern Netherlands OF THE COUNTER-Reformation}

Our analysis of the material surroundings of miracle-working statues of the Virgin touches upon several themes of the recent historiography of Counter-Reformation in the Southern Netherlands. The ubiquity of the shrines, their generic characteristics (both in terms of their appearance and their historiography), and the often close association with natural or seemingly age-old phenomena suggested by their origins or location, all refer to the notion of a sacred landscape. The network of small chapels acts as a Catholic seal in the Brabantine hinterland. Yet, if the miracle books discussed in this article ultimately identify the Virgin or another divine agent as the author of this seal, they also point towards the range of human actors who were involved in establishing, promoting and maintaining a local cult: brotherhoods or neighboring parishes who often organized the processions of a statue, and the parish priests, local elites and religious orders who chose (or refused) to foster a particular cult.

Processions in particular were crucial in the establishment of a new cult, to propagate an existing one or to attract devotion to an image. ${ }^{107}$ They sacralized the bond between the parish church, the parishioners and the chapel. Many of the smaller chapels are situated in rural areas, and by walking and carrying the image around, the processioners sanctified the hinterland, exemplifying the claim of the Church on 'sacred space'108 - often in opposition to the local landlords. ${ }^{109}$ In Basse-Wavre, annual processions commemorated the healing miracles that occurred when the shrine was in a

107. In B. De Los Rios y Alarçon, Histoire de l'image miraculeuse, p. 14-20, for instance, the description of the festivities along the definitive transfer of Our Lady of Good Success to the Augustinian church, presents them as an integral part of the establishment process of the image in its new place of worship.

108. On this subject, see Sarah Hamilton ant Andrew Spicer, "Defining the Holy: the delineation of Sacred Space", Defining the Holy. Sacred Space in Medieval and Early Modern Europe, eds. Andrew Spicer and Sarah Hamilton, Farnham, Ashgate, 2006, p. 1-23.

109. On this subject, see the forthcoming research of Tom Bervoets, "De kerk in het midden? Parochieclerus, lokale elite en de strijd om de controle over de sacrale ruimte op het 18de-eeuwse Brabantse platteland." Paper presented at the Masterclass: "De Sacrale Ruimte", organised at KU Leuven, September $9^{\text {th }}-10^{\text {th }}$ 2014. 
particular place; from Brussels to the surrounding countryside, they delineate a space subjected to the power of the Virgin. ${ }^{110}$ Of particular importance in this process were brotherhoods - often identified as important actors in miracle booklets - organizations that supported and controlled popular devotion. They organized the processions that progressively substituted individual pilgrimage in the second half of the $17^{\text {th }}$ century. ${ }^{111}$

The existence of the shrines as part of a collective religious practice is also apparent from the emphasis, in the miracle books, on how the cult of a statue instigates recurring 'mass gatherings'. These mass gatherings of devotees - sometimes more than a thousand a day according to legend - are invoked to justify the extension of a chapel, even if the new building would not seat more than a dozen people. This motif is especially present in the case studies of the third type. The chapels in question are often quite small and develop according to the generic process described above. In these cases, sentences like "due to the large amount of devotees visiting the sacred place every day, the chapel had to be enlarged" appear to function mainly as a means for a local patron to legitimize the expansion of a shrine, motivated by other religious or pious considerations, such as a concern for their own salvation. This appears to be the case in Wolvertem ${ }^{112}$ but also in the Our Lady of Good Support in Brussels. ${ }^{113}$ In these instances, a fissure seems to emerge between local elite that consciously drew on an existing body of building myths and historical tropes to justify its undertakings, and a larger audience of devotees who adopted these myths as a means to identify with a particular cult. ${ }^{114}$

110. See L'arche d'Alliance, p. 46-66 and p. 216-223. The miracle booklet emphasizes the miracles that took place during processions with the new shrine from 1628, gifted by the Archbischop J. Boonen after the iconoclasts' destructions from 1580 .

111. Marc Wingens, "De Nederlandse Mariale Bedevaart (ca. 1600 - ca. 1800)", Trajecta, 1, 2, 1992, p. 180-181.

112. Jacques 't Kint, De devotie tot Onze Lieve Vrouw, p. 19.

113. Jean-François Gaucheret, Historie van de Alderheyligste Maget en Moeder Gods Maria, Onder den by-naem van Bystant, Geëert in haere puplieke stads-kapelle binnen de princelyke stad Brussel. Met ophelderinge en redeneringe Over het begin des Christi geloofs in Spagnien, en Over het graf van S. Jacob in Gallicien, Brussels, M. J. G. Simon, 1791, p. 36-37.

114. C. Rudolph, "Building-Miracles as Artistic Justification", p. 409. 
The architecture and decorative elements themselves have a role to play in these processes, as Golsenne explains in his "Ornaments and Cult". ${ }^{115}$ The visual and material apparatus of the chapel or church appeal to the visitors as faithful subjects when they approach the awe-inspiring miraculous object of the statue. A play of mystical 'hide and seek' is put in place. The devotional practice develops according to a sensory dimension: the miraculous image is seen (e.g. in a niche, on an altar or on a pedestal), touched (e.g. relics of contact, prints), heard (e.g. singing, music, voice), even smelled (e.g. in Hoeilaert), but at the same time covered in a cone-shaped dress. The agency of the image is constructed through 'phases of collective belief', as Golsenne puts it, within a specific historical context. ${ }^{116}$ The miraculous statues derive their agency from the context in which they operate. ${ }^{117}$ When the faithful no longer recognize themselves as participants of the cult, the site decays; the cult explains the belief system, not the other way around. ${ }^{118}$ In times of religious prosperity or of challenges - like the $17^{\text {th }}$ century - some sacred places revive and flourish. The cult intensifies and is propagated by means of the historical layering of the narratives. The miraculous aspects of the images are inserted in a teleological legend, which - in our selection of case studies becomes meaningful in the context of the $17^{\text {th }}$ century.

Of particular importance in our understanding of this context is the interplay between the "initiative for the Counter-Reformation from below" and the guidelines for the reestablishment of the Catholic faith "from above". ${ }^{119}$ The devotional "practices" - described in

115. T. Golsenne, "Parure et Culte", p. 81.

116. Ibid., p. 76-77.

117. Hans Belting, Image et Culte. Une Histoire de l'Image avant l'Époque de l'Art, Transl. Frank Muller, Paris, Éditions du Cerf, 1998, p. 12-13.

118. T. Golsenne. "Parure et Culte", p. 77. S. Schoutens, Maria's Brabant, p. 186: "Deze godsvrucht bleef bloeien totdat de Fransche omwenteling de kapel met al hare goederen aansloeg en verkocht. Het beeld nogtans werd gered en verborgen totdat de dagen van vrede voor den godsdienst aanbraken. Dan stelde men het op zijn altaar terug; doch dewijl de bidplaats van alle hare goederen beroofd was, en de inwoners van Calevoet ze niet onderhielden, kon er ook de goddelijke dienst geen plaats meer hebben."

119. As we determined from the active involvement of the successive Archbishops of Mechelen described in miracle booklets. For research on Matthias Hovius, Archbischop of Mechelen (1596-1620), see Eddy Put and Craig Harline, "Dagboek van een aartsbisschop. Een portretstudie van Matthias Hovius (1542-1620)" Trajecta, 3, 1, 1994, p. 19-33. 
detail in texts and illustrations such as the miracle books - reflect popular customs but also seem to support the initiatives of the ecclesiastical authorities. If authors like Judith Pollmann and Peter Burke saw a dichotomy between processes of Catholic restoration initiated 'from below' and 'from above', ${ }^{120}$ we propose, following Peter Toebak, to understand the material surroundings of the miracleworking statues, including the architecture, as a bridge between this so-called 'small' and 'large tradition'. ${ }^{121}$ As the miracle books and material context of the statues suggest, the Marian chapels are physical traces of processes that involved the variety of groups that have been identified as actors in the Counter-Reformation in the Southern Netherlands. At the same time, we hope to have shown that the discovery, establishment and subsequent worship of the statues generate a visual and material culture whose principles and mechanisms are not confined to the historical moment of the $17^{\text {th }}$ century.

maarten.delbeke@ugent.be

Department of Architecture and Urban Planning

Ghent University - Faculty of Engineering and Architecture

Jozef Plateaustraat 22

9000 Gent

lise.constant@uclouvain.be

lobke.geurs@gmail.com

anneliesstaessen@yahoo.com

120. Peter Burke, Volkscultuur in Europa (1500-1800), Amsterdam, Agon, 1990, p. 37-42. Judith Pollmann based her research on diaries and memoires of middle-class urban contemporaries and concluded that the initiative for the Counter-Reformation came primarily 'from below'. Judith Pollmann, Catholic Identity and the Revolt of the Netherlands 1520-1635, Oxford, Oxford University Press ("The Past \& Present Book Series"), 2011.

121. Peter Toebak, "Het kerkelijk-godsdienstige en culturele leven binnen het Noordwestelijke deel van het Hertogdom Brahant (1587-1609). Een typering." Trajecta, 1, 2, 1992, p. 126. 

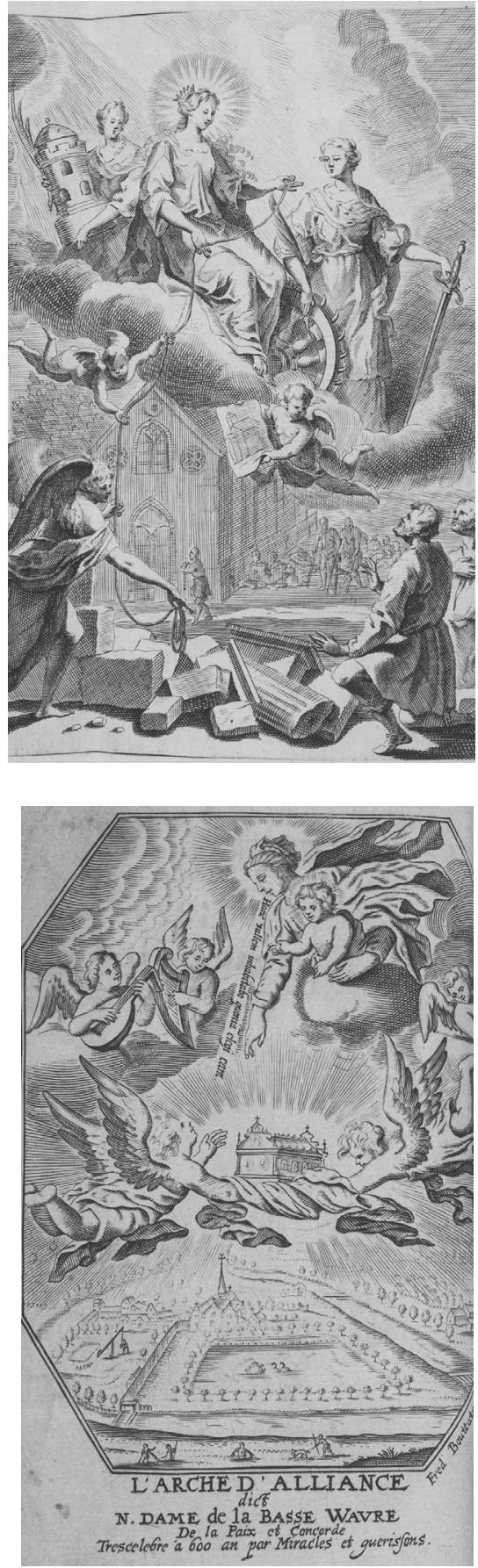

Fig. 1: Appearance of the Virgin, St Barbara and St Catherine, to lay out the plan of the church of Laken. Engraving inserted in Quentin Hennin, Oorspronk Van de Kercke van Laken ofte d'Eerste zeghen-teekenen der Christene Wapenen, onder den Keyser Arnulphus Coninck van Beyeren, Glorieuselyck over 800 Jaeren in de Nederlanden behaelt, Door de Nederlaege der Noormannen. Op-gerecht ter eeren van d'Alderhheylighste Moeder Godts Maria in Laken..., Brussels, J. Stryckwant, 1694. Brussels, KBR, Handschriften, G 667 A. (C) KBR, Brussels)

Fig. 2: Frédéric Bouttats junior, The Ark of the Covenant, said Our Lady of Basse-Wavre, of Peace and Concord. Engraving inserted in L'arche d'Alliance ou l'Histoire de Notre-Dame de la Basse Wavre; dict Nostre Dame de Payx et Concord, Brussels, Jacques van de Velde, 1721 [Approbatio 1641]. Brussels, KBR, Kostbare Werken, III 93.482 A. (C KBR, Brussels) 

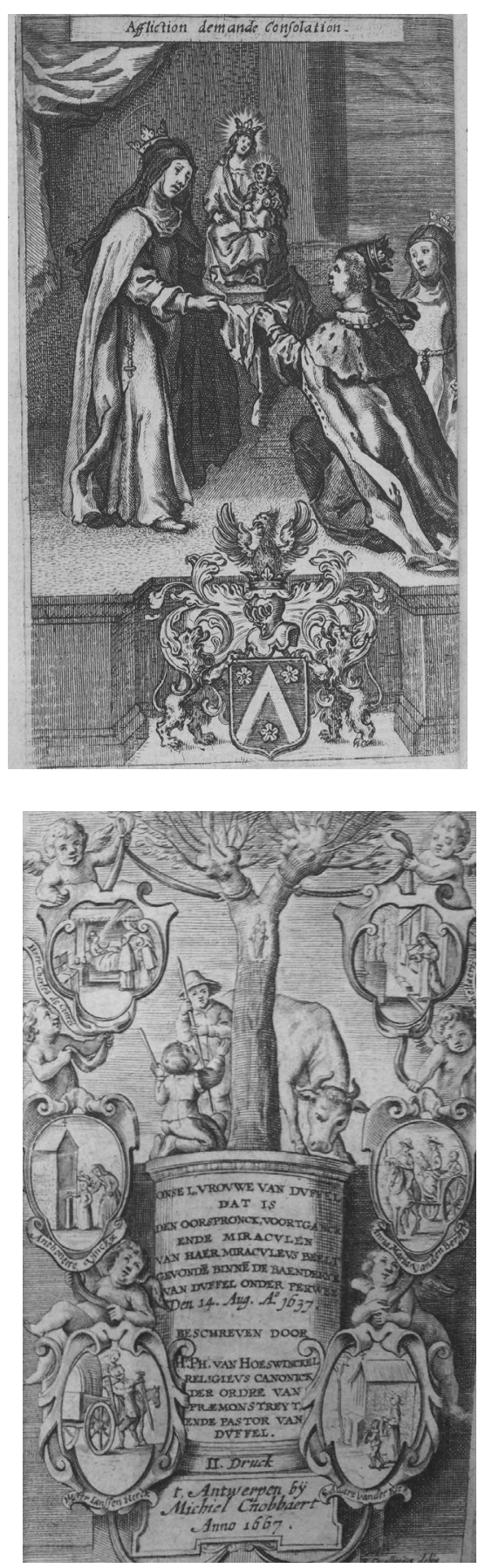

Fig. 3: St Elizabeth gives the statue of Our Lady of Vilvoorde to Sophie. Engraving inserted in Sr. I. Compaignom, Histoire de l'image admirable de Nostre Dame de Consolation, Reverée dans l'Eglise du Monastère des Religieuses Carmélites de Vilvorde, Brussels, Guillaume Scheybels, 1648. Brussels, KBR, Kostbare Werken, VH 25.511 A. (C) KBR, Brussels)

Fig. 4: Our Lady of Duffel in a tree, worshipped by shepherds. Engraved title page of Philippus Van Hoeswinckel, Onse L.Vrouwe van Duffel dat is den oorspronck, voortganck ende miraculen van haer miraculeus beelt gevonden binnen de baenderye van Duffel onder Perwez. Den 14. Aug. A ${ }^{\circ}$ 1637, Antwerp, Michiel Cnobbaert, 1667. KU Leuven, Centrale Bibliotheek, 7A 40351. (C KULeuven, Leuven) 


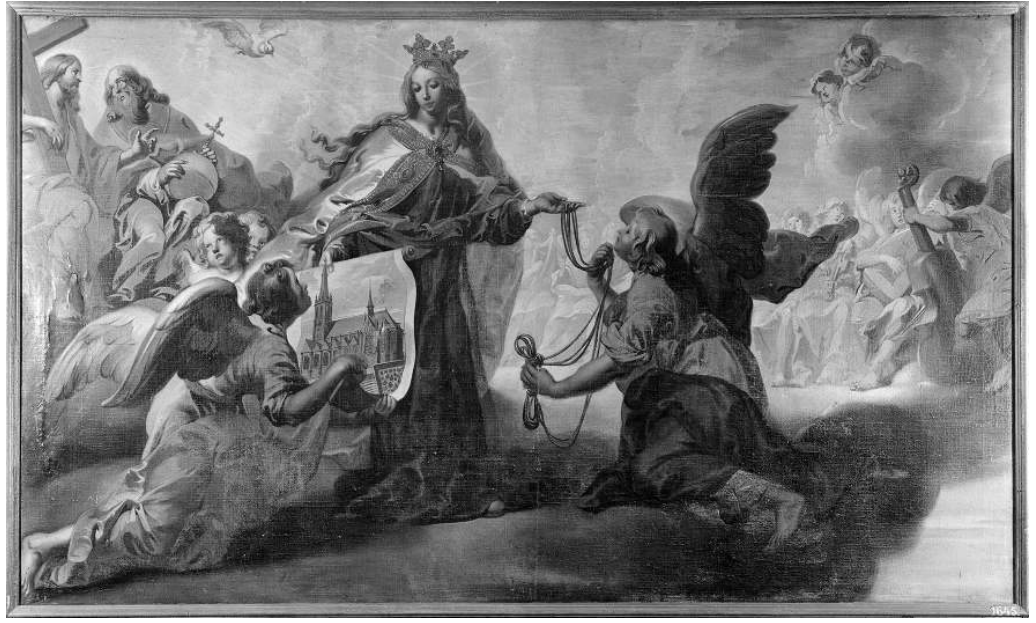

Fig. 5: Antoon Sallaert, The Virgin send angels to tell St Elisabeth of Hungary to build a church in Brabant, 1645-1650. Alsemberg, Our Lady of Alsemberg Church. (C KIK-IRPA, Brussels, B075390, 1944).

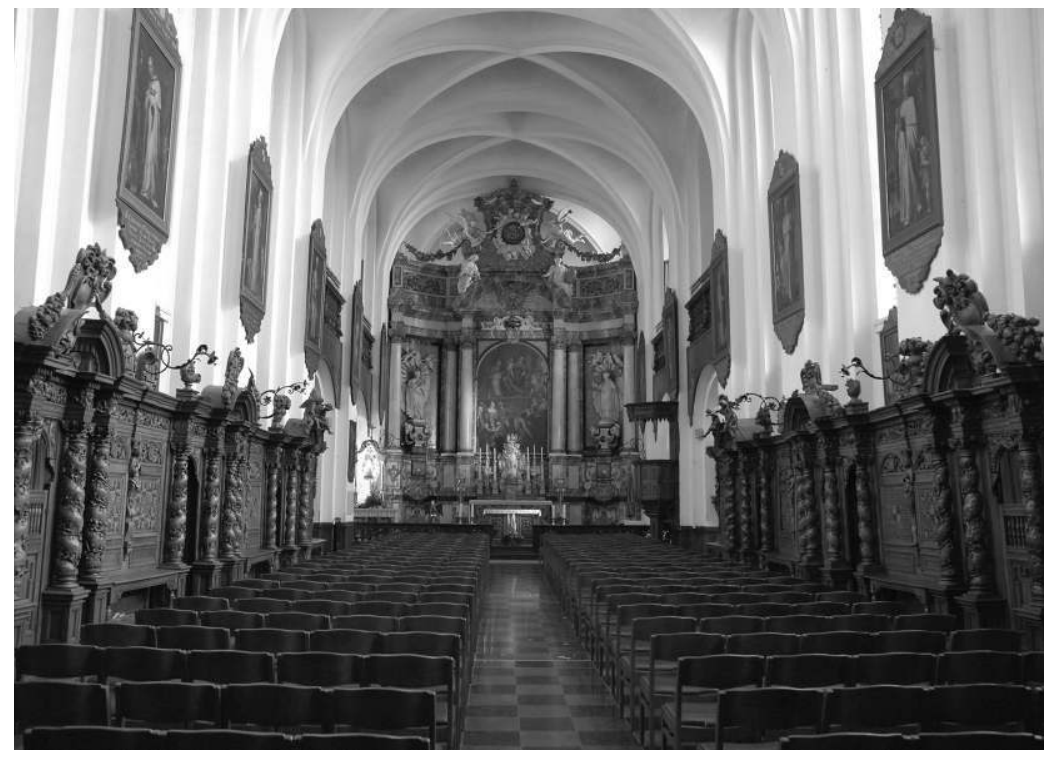

Fig. 6: Kortenbos, Our Lady of Kortenbos Church, interior view of the nave. (Photography A. Staessen, 2013) 


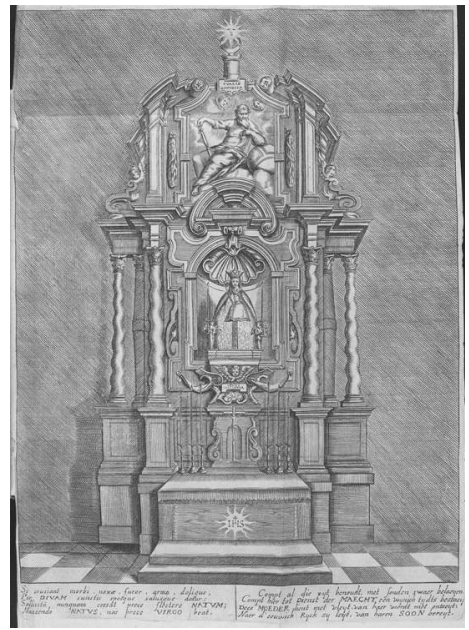

Fig. 7: Jan-Lucas Faydherbe, Sedes Sapientiae altar, 1658. Leuven, St Peter's Church (altar destroyed in 1944). Engraving inserted in Bernardus Heymbach, Diva Lovaniensis seu mira beneficia a dei parente Lovanii ad aram sibi sacram in aede D. Petri Mortalibus Impetrata. Libri tres, Louvain, Cypriani Coenestenij, 1655. Brussels, KBR, Kostbare Werken, VH 27435. (C KBR, Brussels)

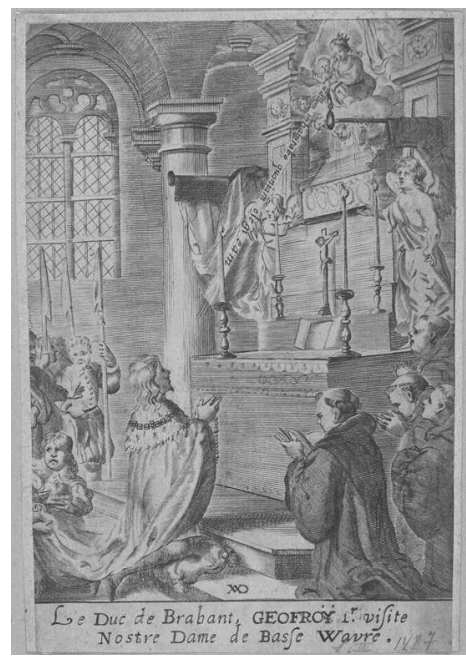

Fig. 8: Antoine Van der Does, Duke of Brabant Godfrey I visits Our Lady of Basse-Wavre. Brussels, KBR, Prentenkabinet, S.III 1487. (C KBR, Brussels) Engraving also inserted in L'arche d'Alliance ou l'Histoire de NotreDame de la Basse Wavre; dict Nostre Dame de Payx et Concord, n.p.n.d. [Approbatio 1641]. Gent, Universiteitsbibliotheek. 


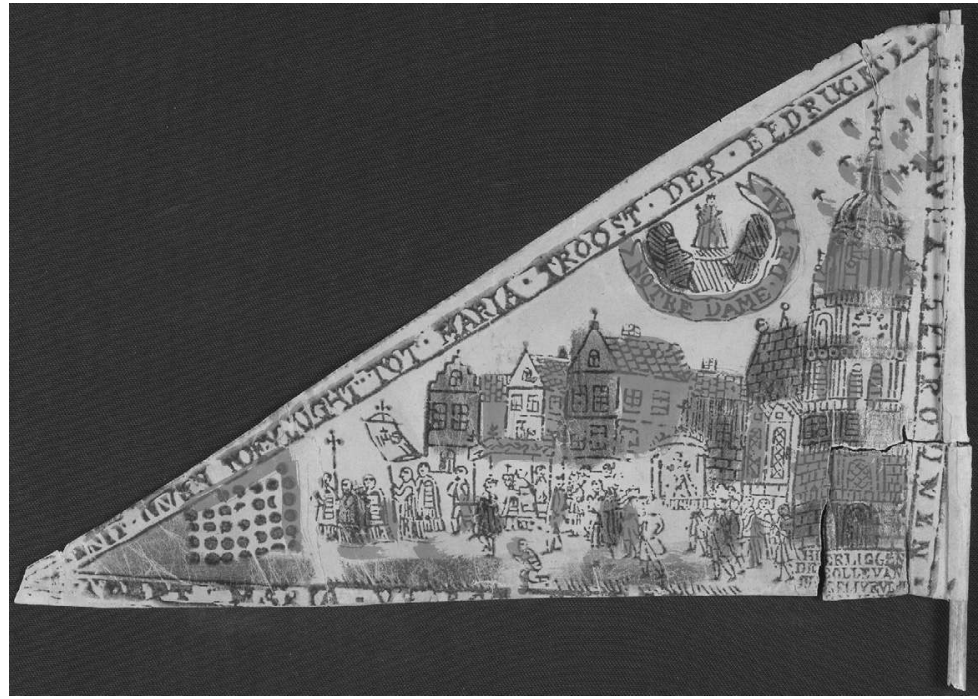

Fig. 9: Pilgrimage pennon of Our Lady of Halle. Brussels, KBR, Prentenkabinet, R/2009/13064. (C KBR, Brussels)

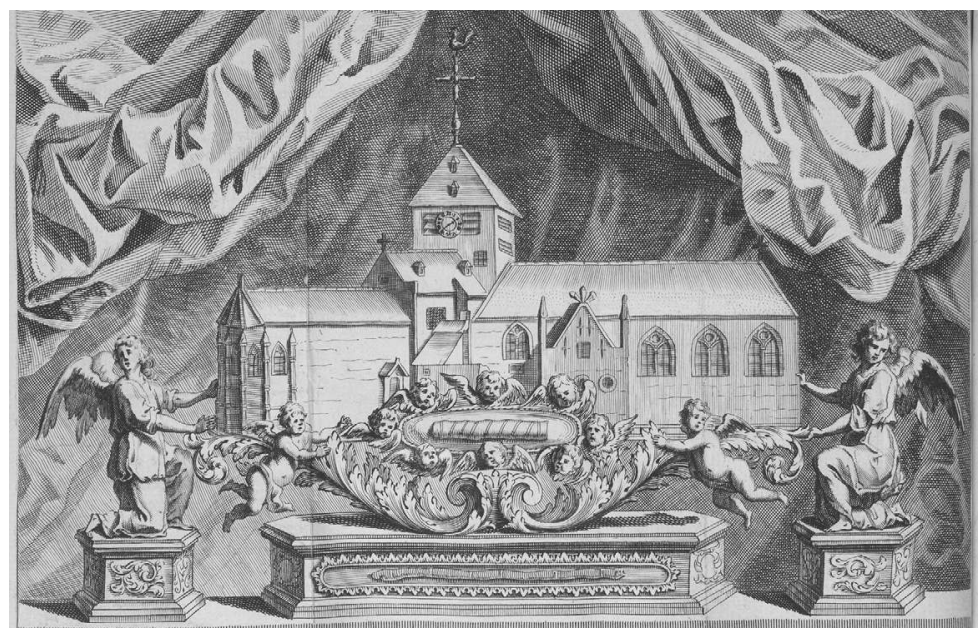

Fig. 10: The miraculous thread in front of the church of Laken. Engraving inserted in Quentin Hennin, Oorspronk Van de Kercke van Laken ofte d'Eerste zeghen-teekenen der Christene Wapenen, onder den Keyser Arnulphus Coninck van Beyeren, Glorieuselyck over 800 Jaeren in de Nederlanden behaelt, Door de Nederlaege der Noormannen. Op-gerecht ter eeren van d'Alderhheylighste Moeder Godts Maria in Laken... Brussels, J. Stryckwant, 1694. Brussels, KBR, Handschriften, G 667 A. (C KBR, Brussels) 


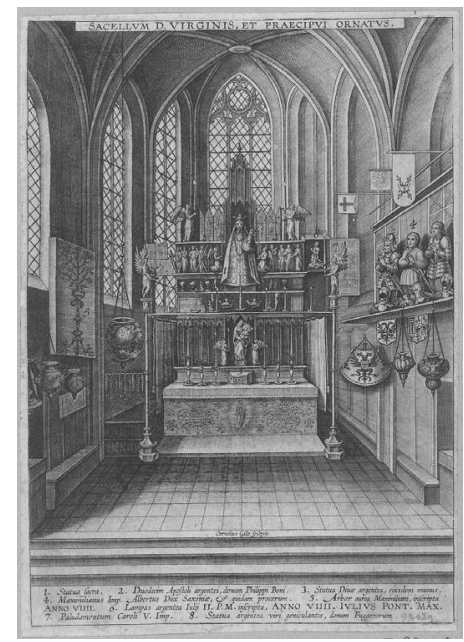

Fig. 11: Cornelius Galle, Our Lady of Halle Chapel and its main ornaments. KBR, Prentenkabinet, S. II 92039. (C KBR, Brussels)

Engraving also inserted in Justus Lipsius, Diva Virgo Hallensis. Beneficia eius \& Miracula fide atque ordine descripta, Antwerp, J. Moretus, 1605. Gent, Universiteitsbibliotheek.

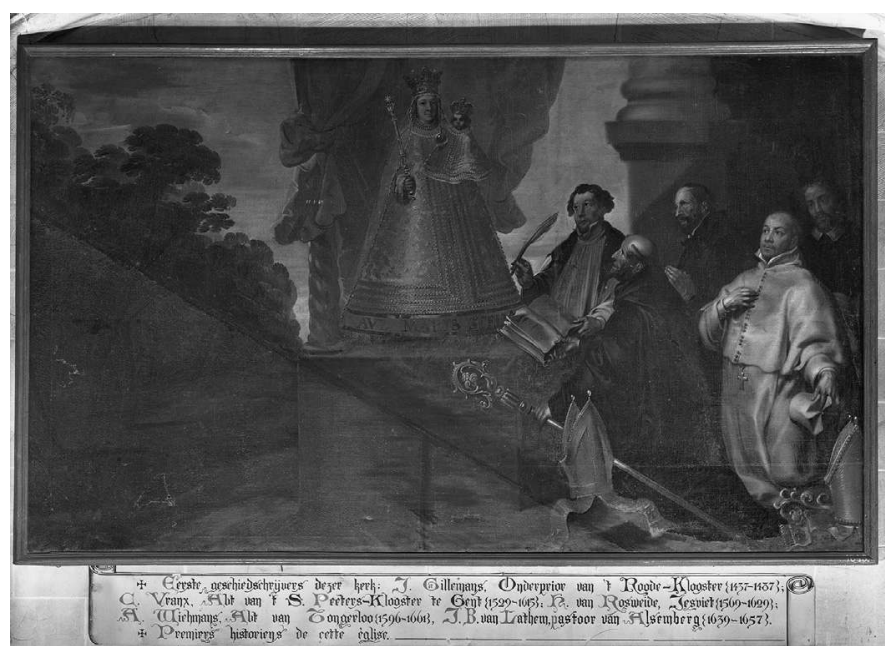

Fig. 12: Antoon Sallaert, First chroniclers of the church Our Lady of Alsemberg: J. Gillemans, Sub-prior of 't Roode-Klooster (1437-1487); C. Vranx, Abbot of St Peter cloister in Ghent (1529-1615); F. van Rosweide, Jesuit (1569-1629); A. Wichmans, Abbot of Tongerloo (1596-1661); J.B. van Lathem, pastor of Alsemberg (1639-1657), 1645-1650. Alsemberg, Our Lady of Alsemberg Church. (@ KIK-IRPA, Brussels, B075382, 1944). 


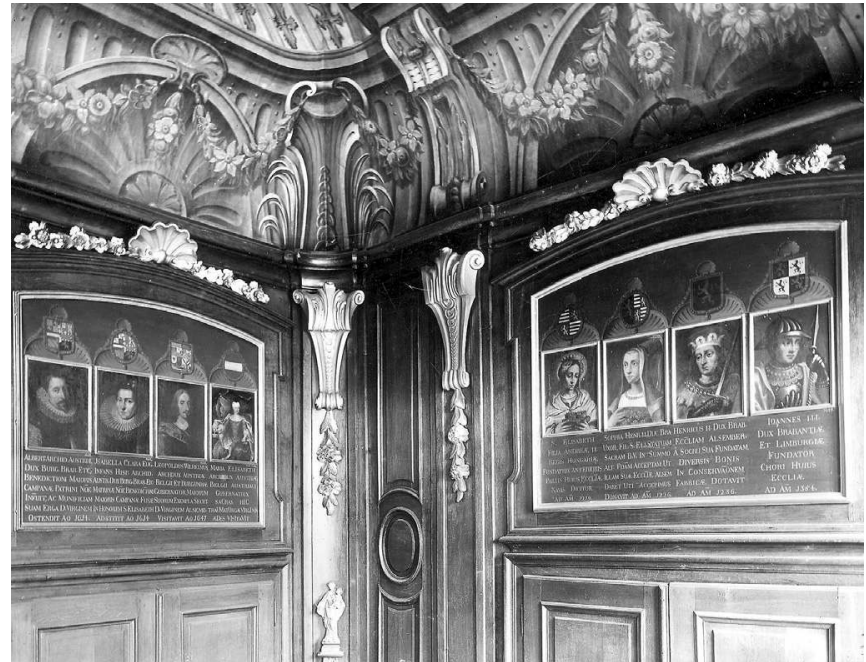

Fig. 13: Alsemberg, Church Our lady of Alsemberg, Sacristy paneling: Archdukes Albert and Isabella, Leopold Wilhelm and Maria Elizabeth of Austria ; St Elisabeth, Sophie, Henry II of Brabant and John III of Brabant, 1657-1732. (@ KIK-IRPA, Brussels, B070092, s.d.)

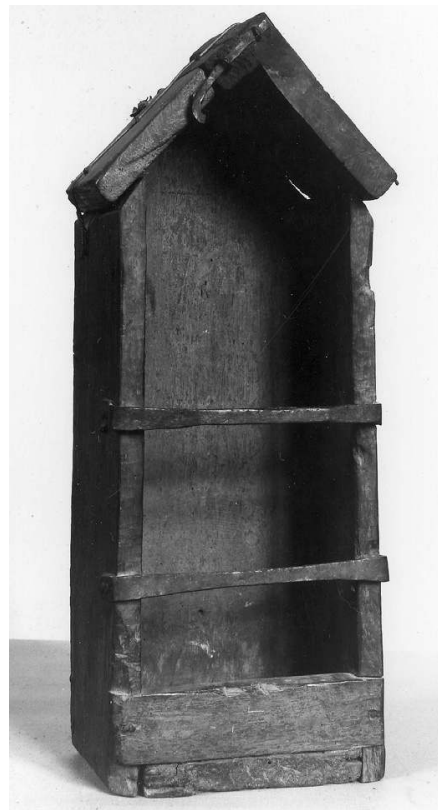

Fig. 14: Wooden niche, $17^{\text {th }}$ century. $57,5 \times 15 \times 21 \mathrm{~cm}$. Overijse, Our Lady of Jezus-Eik Church. (@ KIK-IRPA, Brussels, M249871, 1976) 


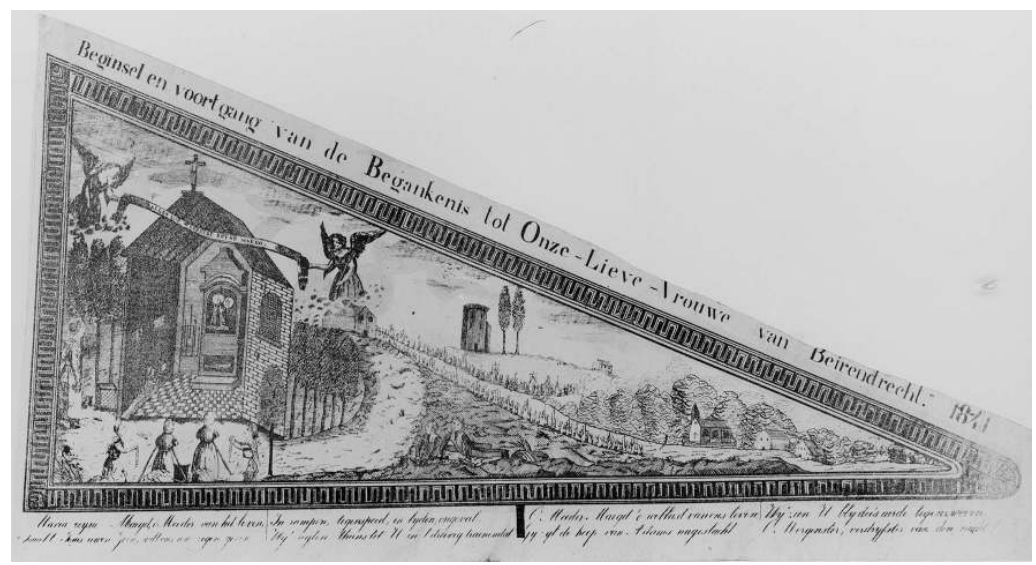

Fig. 15: Pilgrimage pennon of Our Lady of Berendrecht (O.-L.-V. van de Hagelberg), 1841. Antwerp, Volkskundemuseum, M.F.A.60.108.39. (C) KIK-IRPA, Brussels, M170468, 1982)

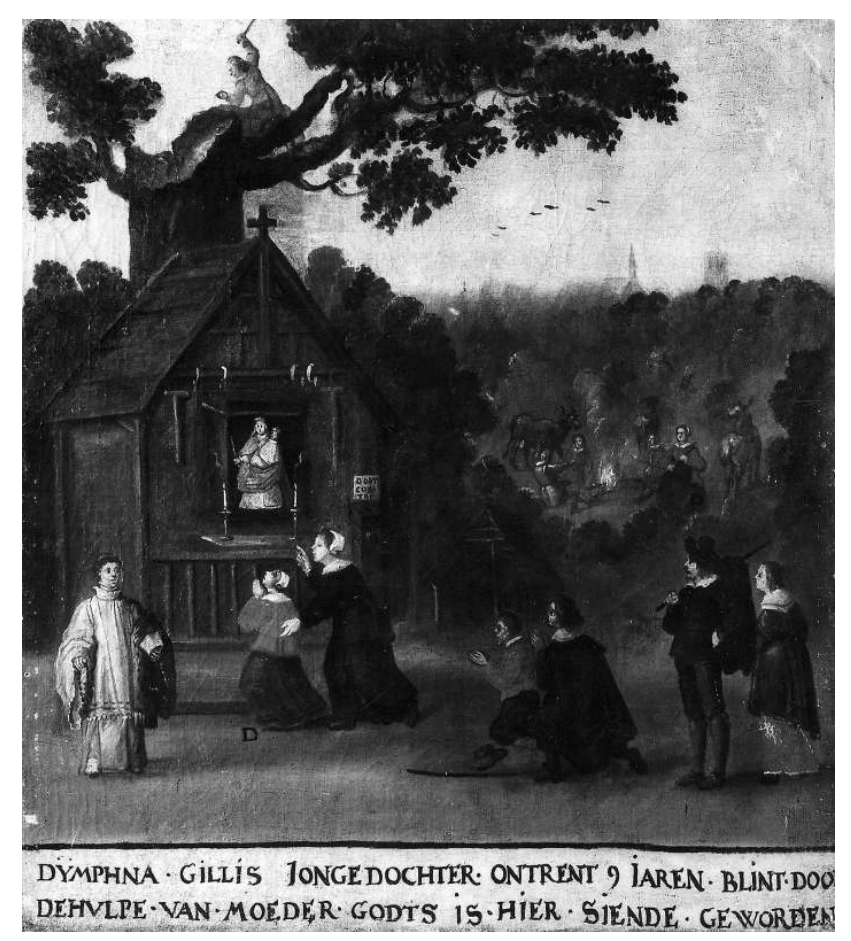

Fig. 16: Healing of Dymphna Gillis thanks to Our Lady, $18^{\text {th }}$ century. Overijse, Our Lady of Jezus-Eik Church. (C) KIK-IRPA, Brussels, M110937, 1973) 


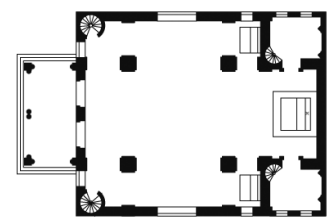

a. Duffel

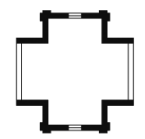

b. Minderhout

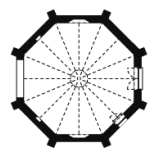

○ d. Duffe

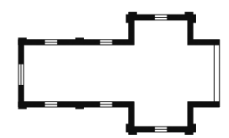

(1) e. Minderhout

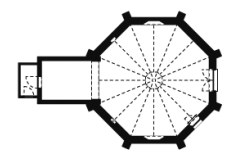

c. Retie

$\ominus \quad$ f. Retie

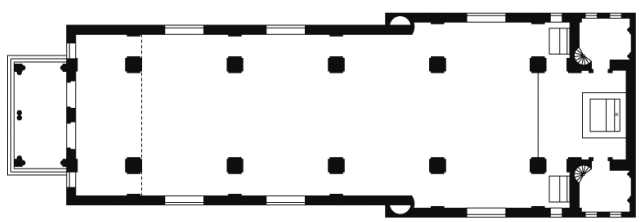

(1)

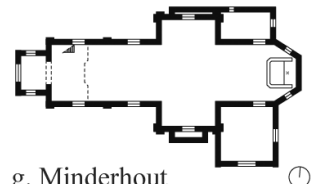

g. Minderhout

Fig. 17: Stone chapels with a central plan: a. Duffel (1639-1642) b. Minderhout (1650) - c. Retie (1665). First extension of stone chapel with a central plan: d. Duffel - e. Minderhout (1688) - f. Retie. Second extension of stone chapels with a central plan: g. Minderhout (1691-1745). (Plans A. Staessen) 


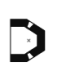

a. Wever

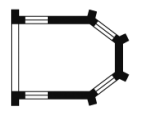

b. Zemst

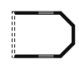

c. Wolvertem

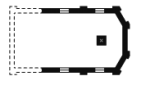

d. Berendrecht

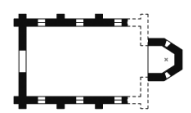

h. Wever

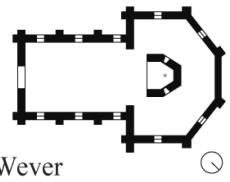

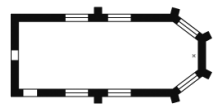

i. Zemst

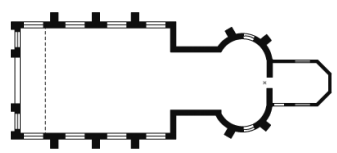

j. Wolvertem

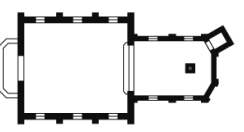

k. Berendrecht

$\theta$

\section{e. Heffen}
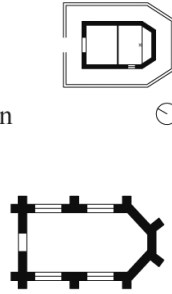

f. Amelgem

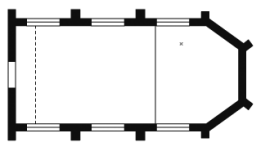

g. Oud-Heverlee

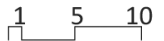

Fig. 18: Stone chapels with a rectangular single-nave plan: a. Wever (1572) - b. Zemst (1669) - c. Wolvertem (1695) - d. Berendrecht (1734) - e. Heffen (1643) - f. Amelgem (1637) - g. Oud-Heverlee (1651). First extension of stone chapels with a rectangular single-nave plan: h. Wever (ca. 1900) - i. Zemst (1699) - j. Wolvertem (1707) - k. Berendrecht (1925). Second extension of stone chapel with a rectangular single-nave plan: 1. Wever (ca. 1922). (Plans A. Staessen) 


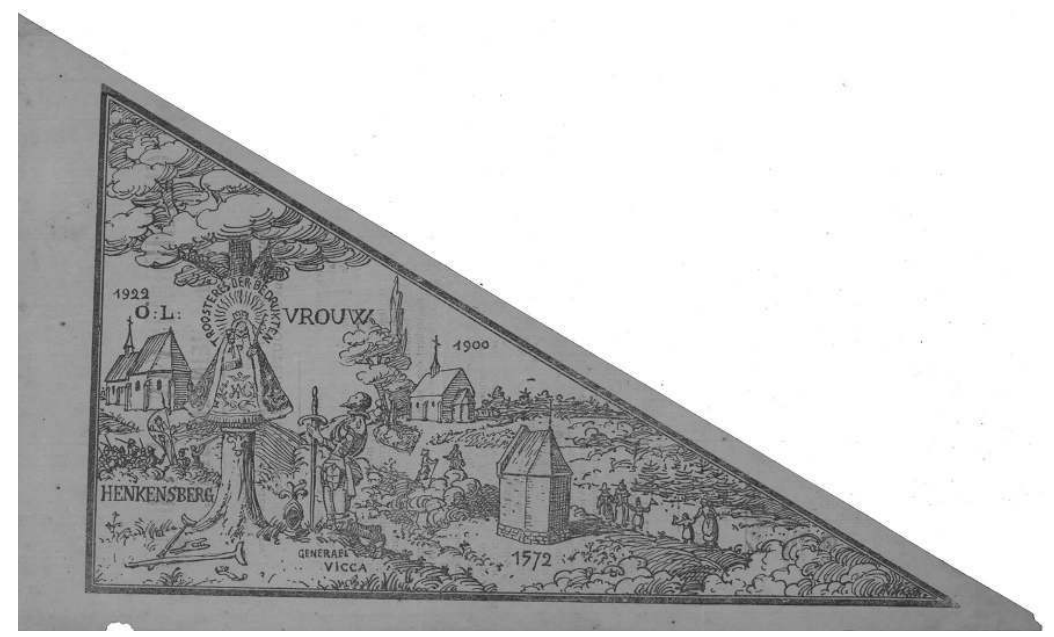

Fig. 19: Pilgrimage pennon of Our Lady of Wever (O.-L.-V. van den Heinkensberg). KU Leuven, KADOK, KVA155. (C) Repro KADOK - KU Leuven, KVA155) 